I N T ER N ATIONAL MONETARY FUND

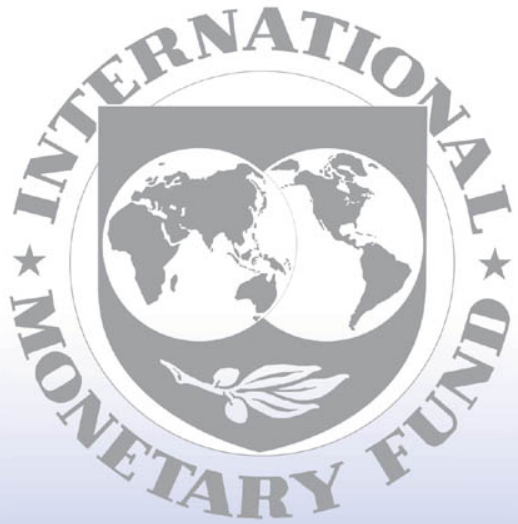

Staff

Country

Reports 


\section{Kingdom of Swaziland: Selected Issues and Statistical Appendix}

This Selected Issues paper and Statistical Appendix for the Kingdom of Swaziland was prepared by a staff team of the International Monetary Fund as background documentation for the periodic consultation with the member country. It is based on the information available at the time it was completed on October 2, 2008. The views expressed in this document are those of the staff team and do not necessarily reflect the views of the government of the Kingdom of Swaziland or the Executive Board of the IMF.

The policy of publication of staff reports and other documents by the IMF allows for the deletion of market-sensitive information.

Copies of this report are available to the public from

International Monetary Fund $\bullet$ Publication Services

700 19th Street, N.W. • Washington, D.C. 20431

Telephone: (202) 6237430 • Telefax: (202) 6237201

E-mail: publications@imf.org • Internet: http://www.imf.org

Price: $\$ 18.00$ a copy

\section{International Monetary Fund \\ Washington, D.C.}


This page intentionally left blank 


\section{INTERNATIONAL MONETARY FUND}

KINGDOM OF SWAZILAND

\section{Selected Issues and Statistical Appendix}

Prepared by a staff team consisting of Wipada Soonthornsima (Head), Thomson Fontaine, Alfredo Torrez, and Hamid Davoodi (all AFR)

Approved by the African Department

October 2, 2008

Contents

Basic Data

I. The Role of Non-Bank Financial Institutions in Botswana, Lesotho, Namibia and Swaziland

Introduction.

II. Overview of the role of NBFIs in Developing Countries

III. Characteristics of the Non-bank financial institutions in Botswana, Lesotho, Namibia, and Swaziland.

IV. Non-bank financial institutions the financial system and the real economy ....................14

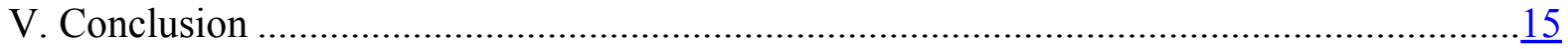

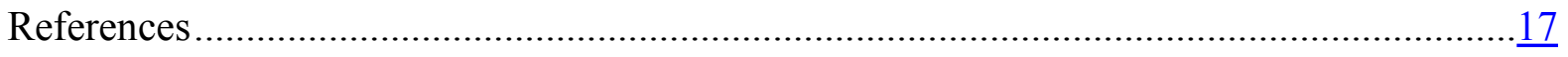

Statistical Tables

1. Gross Domestic Product by Sector of Origin at 2000 Constant Prices, 2003-07 ...............19

2. Gross Domestic Product by Sector of Origin at Current Prices, 2003-07.........................20

3. Gross Domestic Product by Expenditure Category at Current Prices, 2003-07 ................ 21

4. Population and Labor Force Estimates, 2002-07 ......................................................... $\frac{22}{23}$

5. Developments in Crop Production, 2002/03-2006/07.................................................23

6. Developments in Sugar Production, Processing, and Consumption, 2002/03-2006/07......24

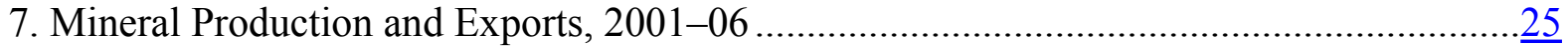

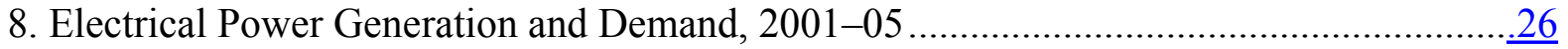

9. Retail Price Indices of Urban Families, 2003-08 …..................................................... $\frac{27}{28}$

10. Minimum Wages for General Workers in Selected Industries, 2002-06 ........................ $\frac{28}{29}$

11. Paid Employment in the Private and Public Sectors by Industry, 2002-05 ....................29

12. Summary of Central Government Operations, 2003/04-2007/08 …............................ $\frac{30}{31}$

13. Central Government Revenue and Grants, 2003/04-2007/08 ........................................ 
14. Functional Classification of Central Government Expenditure and Net

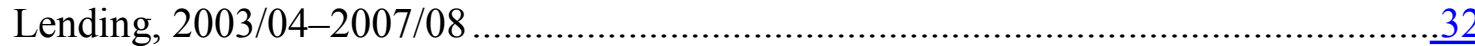

15. Economic Classification of Government Current Expenditure, 2003/04-2007/08 …….....33

16. Capital Expenditure by Sector, 2003/04-2007/08 ……….............................................

17. Government Transfer Payments, 2003/04-2007/08 …………………………...........

18. Flow of Funds From the Government to Public Enterprises 2003/04-2007/08 ……..........

19. Outstanding Domestic Government Debt by Type of Instrument, 2003-08 …...................

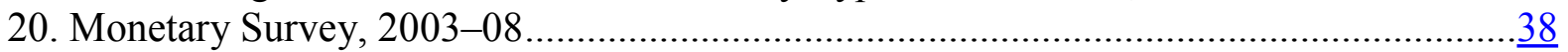

21. Assets and Liabilities of the Central Bank of Swaziland, 2003-07 ...................................

22. Assets and Liabilities of Commercial Banks, 2003-07 .................................................

23. Commercial Banks' Deposits by Sector, 2003-07 ……..............................................

25. Commercial Bank Loans and Advances by Category of Borrower, 2003-07 ...................43

26. Interest Rates in Swaziland and South Africa, 2003-08..............................................4

27. Balance of Payments, 2003-07 …………………………………………….......

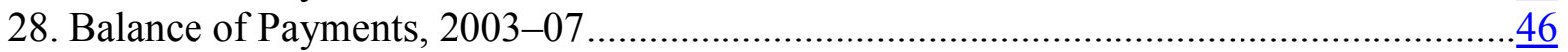

29. Merchandise Exports, 2003-07 ..............................................................................47

30. Sugar Exports by Volume, Value, and Unit Price, 2003-07 ……………………......... 48

31. Other Principal Exports by Volume, Value, and Unit Price, 2003-07 ………................. 49

32. Merchandise Imports, 2003-07 …………………..........................................

33: Services and Income Account, 2003-07 .............................................................

34. Financial Account, 2003-07 ................................................................................

35. Public Sector External Debt, 2003-07 ………........................................................

36. Public Sector External Debt Service, 2002/03-2007/08................................................

37. Commercial Banks' Performance Ratios, Dec. 2003-08 …………………………..........

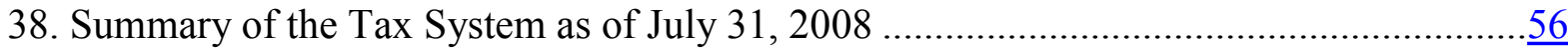




\section{SWAZILAND: BASIC DATA}

Area (square kilometers )

Population (2006)

Population growth rate (2006) in percent

Formal employment (2005)

IMF Position (Janurary 3, 2008)

Quota

Fund holdings of emalangeni

Holdings of SDRs

Exchange rate as of August 31, 2008
17,364

$1,018,449$

0.38

92,102

SDR 50.70 million

SDR 44.15 million

SDR 2.55 million

US\$1 = E 7.69

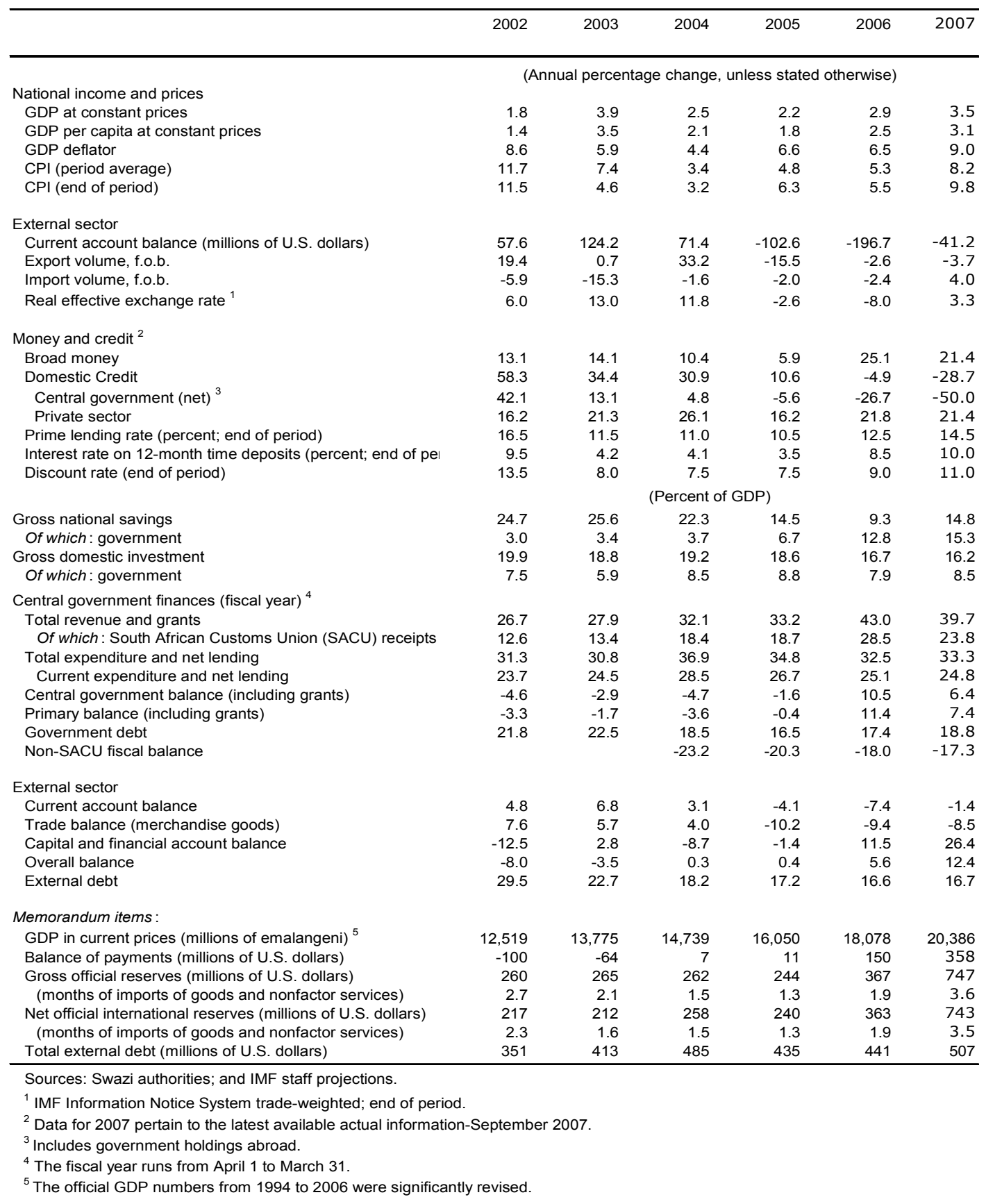




\section{SWAZILAND: The Role OF Non-BAnk FinanCial InSTITUTIONS In Botswana, LESOTHO, NAMIBIA AND SWAZILAND ${ }^{1}$}

\section{A. Introduction}

1. A country's financial structure plays a crucial role in helping to generate growth and in contributing to overall macroeconomic stability. Non-bank financial institutions (NBFIs) contribute by providing an alternative to banks to translating household savings into enterprise investment while spreading associated risks and allocating funds for investment purposes. NBFIs mainly include leasing and venture capital companies as well as various types of contractual savings and institutional investors such as pension funds, insurance companies, and mutual funds. In Botswana, Lesotho, Namibia and Swaziland, the contractual savings sector dominates the NBFIs. Other NBFIs in these countries comprise credit cooperatives, unit trusts, brokers of various vocations, asset and fund managers, and various types of micro lenders. ${ }^{2}$

2. With the exception of South Africa, the financial systems of Southern African Customs Union (SACU) countries-- Botswana, Lesotho, Namibia and Swaziland --are in the nascent stages and thus leave ample opportunity for the widespread development of NBFIs. Several factors have aided in the promotion of NBFIs in SACU countries, key among which is stable economies, a pool of available savings, domestic investment requirements, and a banking system that serves the needs of too few players in the economy. In Swaziland during 2008 the number of NBFIs is growing significantly as they attempt to take advantage of the liquidity surge from the requirement that insurance and retirement funds must increase their holdings of domestic assets from 10 to 30 percent of total assets by 2009 . However, the lack of adequate legal and regulatory supervision may have influenced negatively the activities of this sector and limited its potential contribution to economic growth.

3. NBFIs can be seen as either complementing the role of commercial banks or acting in direct competition with banks by forcing them to be more efficient and responsive to the needs of their customers. The degree to which NBFIs succeed in filling the gaps in services left by the commercial banks depend greatly on the sophistication of a country's financial system. It also depends on the ease of access to formal financial services, the level of financial sophistication, and average income levels. In many sub-Saharan African (SSA) countries, pervasive rural poverty, and widespread unemployment have facilitated an unprecedented growth in NBFIs that have stepped in to meet the needs of those underserved by the relatively small formal financial sector.

\footnotetext{
${ }^{1}$ Prepared by Alfredo Torrez and Thomson Fontaine.

${ }^{2}$ Stock Exchange can also be included as part of the non-bank financial institutions.
} 
4. In all the SACU countries, the total assets of NBFIs are far larger than that of the commercial banks. Table 1 presents information on NBFI assets.

Table 1: Total Assets of Banks and Non Bank Institutions

\begin{tabular}{rrrrrrrr}
\hline Banks & $\begin{array}{l}\text { Non- } \\
\text { Banking }\end{array}$ & Insurance & \multicolumn{2}{c}{$\begin{array}{l}\text { Investment } \\
\text { Pension Funds Funds }\end{array}$} & $\begin{array}{l}\text { Building } \\
\text { societies }\end{array}$ & $\begin{array}{l}\text { Savings / } \\
\text { credit unions }\end{array}$ & Other \\
\hline 60 & 81 & 21 & 48 & - & 2 & 4 & 6 \\
42 & 23 & 18 & 5 & - & - & - & 0.2 \\
85 & 90 & 36 & 54 & - & - & - & 1 \\
31 & 54 & 2 & 41 & - & 3 & 2 & 6 \\
120 & 208 & 79 & 95 & 35 & - & - & - \\
\hline
\end{tabular}

Source: Various IMF reports and country authorities.

5. The Common Monetary Area (CMA) agreement among members-- Lesotho, Namibia, South Africa, and Swaziland--has allowed and facilitated the entrance of shareholders from South Africa in the banking and NBFI sectors. The CMA agreement eliminates currency risk and facilitates foreign portfolio investments among their members. Furthermore, it has imposed a limit on non-CMA investments that have motivated the entrance of South African companies in most financial institutions within the CMA.

\section{This paper attempts to take a closer look at NBFIs operating in Botswana,} Lesotho, Namibia and Swaziland. Section II reviews the literature on the role of NBFIs in low income countries and the factors influencing their development. The particular characteristics of the NBFIs in the four countries are the focus in section III. Section IV assesses the interaction of the NBFIs within the financial system and the real economy, and Section V provides some conclusions on the lessons and policy implications of the growing role of NBFIs in the four countries.

\section{OVERVIEW OF THE ROLE OF NBFIS IN DEVELOPING COUNTRIES}

\section{McKinnon along with Edward Shaw are often credited with fundamentally} changing the way that development economists thought about the contributions of money and finance to economic development. However, it was the earlier work of Raymond Goldsmith that had identified the key processes involved in financial development and the conditions under which financial systems deepen over time. In Goldsmith's view increased economic activity and the consequent rise in income levels contributed to expanded financial intermediation and a build up of financial assets and liabilities. The increased intermediation is due to an expansion of traditional commercial banking activities and an extended role for NBFIs. 
8. King and Levine (1993a) and King and Levine (1993b), developed cross country analysis that appear to provide support for the view that finance promotes growth. Other studies including that of Deidda and Fattah (2002) and Harris (1997) however, indicates that, while being strongly positive at relatively high levels of per-capita income, the relation between financial development and growth is generally weak or insignificant at relatively low levels of per-capita income. Evidence has even been found of a negative relationship as is the case in $\mathrm{Nu}$ (2000). Historical country-studies such as Cameron (1967) and McKinnon (1989) suggest that whether financial development effectively drives subsequent economic growth or not depends ultimately on the efficiency of the financial institutions.

9. Gurley and Shaw (1955) in noting the increasing importance of NBFIs argued that their activities posed potentially serious problems for monetary management and policy. There is recognition that NBFIs assumed significantly larger roles even as monetary authorities placed specific restriction on banks thus enabling them to provide services in the newly created space. Additionally, they argued that economic growth stimulates financial market development, and financial market development is a strong contributing factor in enhancing real growth.

10. The growth of the NBFIs in Botswana, Lesotho, Namibia and Swaziland has been facilitated by a combination of relatively small financial sector, and the high costs associated with using formal banking services. Further, access to banking services is generally not available to certain segments of the population such as those living in rural areas or without steady incomes. It is among these groups that the NBFIs such as savings and credit cooperatives (SCCOs) and microfinance institutions have found the most resonance. More importantly insufficient regulatory support and coordination among supervisory agencies further weaken effective supervision and prevent regulatory arbitrage.

\section{Earlier IMF studies on the financial sector indicated that the sector needed} reforms to support more efficiently economic development and improve the quality of services available to the poor. ${ }^{3}$ The studies found that there was insufficient financing for the economies in most SSA and LICs. Most sectors of the economy suffered from financing constraints, but agriculture faced the greatest challenges in accessing formal finance. Reasons for low levels of funding include high costs of financing, weak legal and institutional environments, and the relative attractiveness to banks of providing financing. Faced with stagnating private sector credit from the banking sector, several countries in SSA experienced a rapid growth of non bank financial institutions that could provide credit to those without bank access - usually the poor, as well as local small businesses. However, the

\footnotetext{
${ }^{3}$ IMF, Sub-Saharan Africa Financial Sector Challenges, Anne-Marie Gulde, Catherine Patillo, and Jacob Christensen, 2006.
} 
expansion of these institutions was not accompanied by adequate regulatory and supervisory frameworks, which has resulted in some threat to financial stability.

Table 2: Number of Banks and Non-Bank Financial Institutions

\begin{tabular}{|c|c|c|c|c|c|}
\hline Financial Institutions & Botswana & Lesotho & Namibia & Swaziland & $\begin{array}{l}\text { Deposit Taking } \\
\text { Institution? }\end{array}$ \\
\hline Banks & 11 & 3 & 7 & 5 & \\
\hline Commercial banks & 6 & 3 & 4 & 4 & \\
\hline Foreign controlled bank & 6 & 3 & 3 & 3 & Yes \\
\hline Domestic owned bank & 0 & 0 & 1 & 1 & Yes \\
\hline Investment bank & 1 & & & & No \\
\hline Development banks & 2 & & 2 & & No \\
\hline Savings bank & 1 & & & & Yes \\
\hline Building Society & 1 & & 1 & 1 & Yes \\
\hline Non Bank Financial Institutions & 827 & 186 & 953 & 265 & \\
\hline Development financial institutions & 1 & & 2 & 1 & No \\
\hline Pension Funds & 115 & & 550 & 200 & No \\
\hline Of which: Government Pension Fund & 1 & 1 & 1 & 2 & \\
\hline Insurance Cias & 54 & 4 & 32 & 5 & No \\
\hline Of which : Foreign controlled & 4 & & 28 & & \\
\hline Insurance brokers & 14 & 8 & & & No \\
\hline Credit Cooperatives & 36 & 160 & 52 & 56 & Yes \\
\hline Term lenders & 4 & 13 & & & Yes \\
\hline Cash Lenders & 600 & & & & No \\
\hline Government scheme & 1 & & & & No \\
\hline Post Office savings bank & & 1 & 1 & & Yes \\
\hline Microfinance & & & 256 & $100+$ & No ${ }^{1}$ \\
\hline Asset management Cias. & & & 35 & & No \\
\hline Stock brokers & & & 4 & & No \\
\hline Mortgage and House Cias. & 2 & & 1 & & Yes \\
\hline Credit reference bureaus & & & 2 & & No \\
\hline Others & & & 9 & 1 & No \\
\hline Unit trust & & & 9 & 2 & No \\
\hline Total financial institutions & 839 & 189 & 961 & 271 & \\
\hline
\end{tabular}

Source: Various IMF reports and country authorities.

${ }^{1}$ Some microfinance institutions accept deposits.

\section{ChaRACTERISTICS OF THE NON-BANK FinANCIAL INSTITUTIONS IN BotSWANA, LESOTHO, NAMibia, AND SWAZILAND}

\section{NBFIs are diverse ranging from private money lenders in Lesotho to}

sophisticated capital markets in Namibia. Pension funds, insurance companies, stock exchanges, and SCCOs are by far the most important players within the NBFIs. Other financial intermediaries include fund administrators, unit trusts, assets managers, investment consultants, insurance brokers, dealers, exchange houses; burial societies, special investment vehicles, finance and leasing companies, unit trusts, friendly societies, savings clubs, and others provide myriad financial services. This section focuses on the type of financial instruments issued by NBFIs and their ownership, as well as the regulatory and institutional 
elements under which NBFIs operate. Particular focus will be placed on pension funds, insurance companies, stock exchanges, and SCCOs.

\section{Although having different features, NBFIs have some common characteristics}

that can be used to classify them into deposit taking institutions (e.g., credit unions, credit cooperatives, savings and loans, building and loans, and money lenders) and non-deposit taking institutions (e.g., insurance companies, finance companies, securities dealers, pension funds, etc.). This distinction is important particularly with regards to designing a proper supervision strategy for that sector. For instance, overseeing non-bank deposit taking institutions is closer to banking supervision while regulation and supervision of contractual savings institutions is typically far different.

\section{Credit cooperatives, building societies, and mutual funds, issue liabilities that} can be comparable to liabilities included in the broad measures of money, ${ }^{4}$ while other NBFIs such as leasing, asset management companies, venture capital and private equity firms raise capital not only by direct contribution of shareholders but also by issuing shares and equities, which can be exchanged in capital markets. Some NBFIs have also had limited exposure to the derivatives markets. Financial instruments provided by most SCCOs in Botswana, Lesotho, Namibia, and Swaziland include savings accounts, investment deposits, cooperatives shares of certificates, and car and housing loans. Although these accounts could be easily included in national definitions of broad money and credit they are not since they are not reported regularly to the central bank. Shares in mutual funds, life insurance premiums, reserve pension funds and equity options are also offered in all four countries; and some offer financial consultancy services.

\section{Pension funds main liabilities are members' contribution to retirement}

(employers and employees), as well as returns on their investments. Pension funds do not issue liabilities that are transacted in financial markets (technical reserves of pension funds). Insurance companies that issue insurance policies and annuities are quite different. This is because these liabilities are actuarially based (payments to insurance company policyholders are scheduled based upon expectations of insured events). The assets of pension funds and insurers are typically longer-term and may take the form of equity investment, which are mostly held to maturity. However, the secondary market for these instruments practically does not exist. There is not a substantive market for equities in any of these countries, except for Botswana, where corporations could find opportunities to raise capital. ${ }^{5}$

\footnotetext{
${ }^{4}$ In Swaziland, the building society is supervised by the Bank of Swaziland, and its liabilities are included in broad money supply.

${ }^{5}$ Type of assets carrying by the NBFI include: cash; fixed-income securities and loans; property; participation in real state agencies; shares, share-type securities, cooperative share of certificates; securities of foreign firms quoted on the national stock exchange; investments securities and mutual fund certificates; foreign currency denominated investment.
} 
16. Ownership of NBFIs is mixed, involving both local and foreign. For instance, pension and national provident funds in Botswana, Lesotho, Namibia, and Swaziland are domestically owned. Public government pension funds are the largest, covering on average more than 70 percent of the sector's assets. However, insurance companies in Botswana, Lesotho and Namibia are mostly foreign-owned companies, while in Namibia the reinsurance business is in the hands of the state-owned company. In Swaziland, the oldest and also the largest insurance company --the Royal Insurance Company-- is 40 percent government owned, while recently inaugurated insurance companies have both foreign and domestic shareholders. Meanwhile, SCCOs in each of the countries are domestically owned institutions. Micro lending institutions on the other hand are attached to some NGOs or commercial banks. Similar to the formal banking system, other NBFIs are generally dominated by South African firms.

\section{Several different agencies are responsible for regulating and overseeing the} activities of NBFIs. Pension funds and insurance companies are supervised by the Registrar of pension funds and insurance companies in most countries, while credit cooperatives are under the authority of some government ministries. Central banks are also entrusted to overseeing unit trusts, mutual funds, and financial companies. In the case of Lesotho and Swaziland, the oversight of SCCOs has been in general inadequate, due to lack of comprehensive analysis of the growth of these institutions and the quality of the loan portfolio.

Regulatory Authority (as of end-2007)

\begin{tabular}{|c|c|c|c|c|}
\hline Financial Institutions & Botswana & Lesotho & Namibia & Swaziland \\
\hline Banks & Bank of Botswana (BOB) & Central Bank of Lesotho & Bank of Namibia (BON) & Central Bank of Swaziland (CBS) \\
\hline Insurance Comnanies & Registrar of Insurance, Ministry of Finance and & d Central Banks- Supervision & Namibia Financial Institutions & Registrar of Pension Funds and Insurance \\
\hline insuralice LOMinpalines & Development Planning (MFDP) & Department (CBL-SD) & Supervisory Authority (NAMFISA) & Companies, Ministry of Finance (MF). \\
\hline Pension funds & Registrar of Insurance, MFDP. & CBL-SD & NAMFISA & $\begin{array}{l}\text { Registrar of Pension Funds and Insurance } \\
\text { Companies, MF. }\end{array}$ \\
\hline Investment funds $1 /$ & $\mathrm{BOB}$ & CBL-SD & NAMFISA & CBS/Ministry of Finance \\
\hline Building societies & MFDP & CBL-SD & BON & CBS \\
\hline Credit Cooperatives & Ministry of Trade and Industry & CBL-SD & NAMFISA & $\begin{array}{l}\text { Ministry of Agriculture and Credit } \\
\text { Cooperatives }\end{array}$ \\
\hline Microfinance Institutions & Ministry of Trade and Industry & CBL-SD & NAMFISA & Ministry of Finance \\
\hline Development Banks & $B O B$ & CBL-SD & BON & CBS \\
\hline Discount Houses & $B O B$ & CBL-SD & NAMFISA & CBS \\
\hline
\end{tabular}

\section{Pension Funds and Insurance Companies}

18. Pension funds and insurance companies are by far the most important institutions within the NBFI sector based on their asset holdings. In Botswana, there are 
over 100 private and fully funded pension funds, with total assets at end-2006 amounting to 48 percent of GDP. ${ }^{6}$ Namibia has more than 500 pension funds, with assets estimated at 57 percent of GDP; in Swaziland it is equal to 46 percent of GDP (85 percent of total assets of the NBFI); and in Lesotho just about 10 percent of GDP. The government institutions pension fund in Namibia accounts for about 73 percent of the total assets.

Botswana also operates a social pension system that reached 49

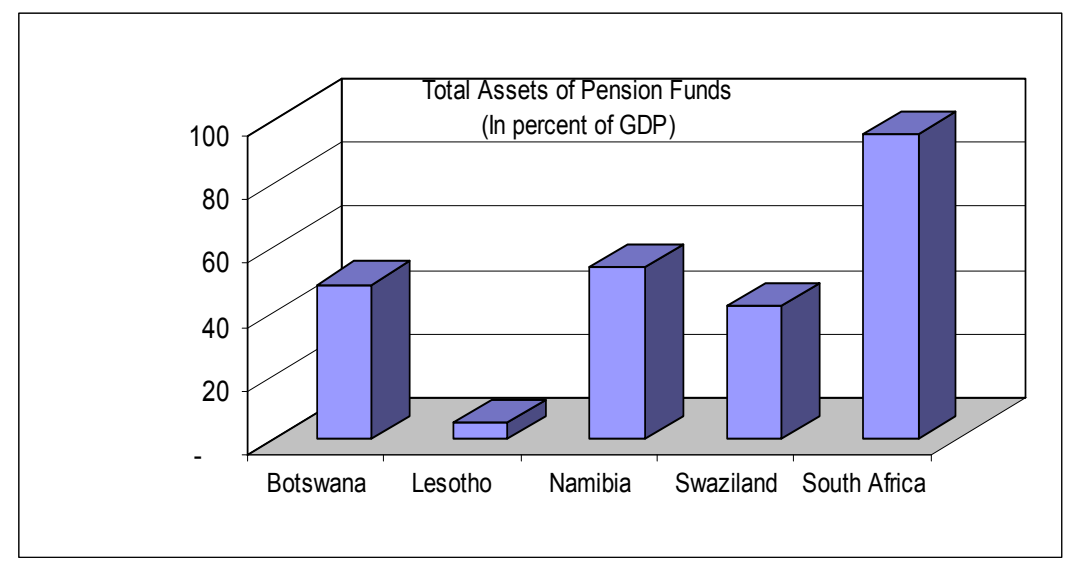
percent of GDP at end 2006. The social funds include in kind support for the Aids orphans.

\section{The development of the insurance sector in Botswana, Lesotho, Namibia and}

Swaziland varies considerably across countries. Income and wealth, macroeconomic stability, and the regulatory framework are the main determinants of insurance business. As in many developing countries, the main line of insurance business in the four countries is compulsory motor insurance, which is often subject to regulation and attracts low premiums. However, in Botswana and Namibia, the markets are much more mature and insurance companies are not only engaged in the insurance of property, life, motor vehicles and heath, but also in the business of re-insurance.

20. In the four countries, the largest pension funds have defined benefit plans. In the case of Swaziland, the Public Service Pension Fund (PSPF) and the Swaziland National Provident Fund's (SNPF) are defined benefit plans and they hope to move to defined contribution plans. While the SNPF covers all public and private employees, the PSPF covers government, prostates, and other public servants. In Lesotho the government is undertaking pension reform that will

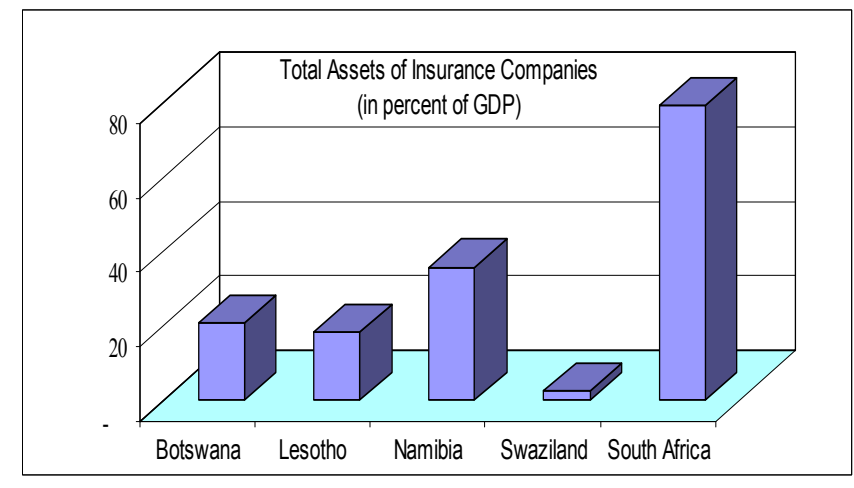
entail switching from the current unfunded defined benefit plan to a pre-funded defined

\footnotetext{
${ }^{6}$ A substantial increase in the assets managed by pension funds followed the conversion of public officers' pension entitlements from defined benefit obligations to defined contribution with the creation of the Botswana Public Officer's Pension Fund (BPOPF) in 2001.
} 
contribution plan. ${ }^{7}$ Namibia and Botswana also have defined benefit plans. In Swaziland and Lesotho, there are substantial annual flows into the pension system and the covered population is relatively young. However, the inflows of the system have been offset by large payments to the HIV/AIDS sufferers.

21. The pension funds and insurance companies invest extensively in overseas assets while also meeting the domestic asset requirements. They also invest a small fraction of their assets in the domestic market, including government bonds and bank deposits. Reasons for investing off-shore include the absence of local investment opportunities and the close financial corporate integration with South African companies. In the case of Namibia, the local investment requirement can be satisfied by investing in domestic government bonds, bank deposits, and securities of domestic companies and in shares of foreign companies with dual listing on the Namibia Stock Exchange. However, Namibia is considering tightening the criteria on domestic investment. Pension and insurance funds have benefited from the relatively strong performance of the South African economy, during the last four years, with good rates of return on investment. In the case of Swaziland, for example, the government pension fund increased its funding position to 95 percent of actuarial liabilities thanks to relatively high returns in South Africa. ${ }^{8}$ In Namibia, returns during 2003-2007 averaged between 3 and 4 percent. In Botswana, the lack of long-term local assets has led pension funds to invest a large share of their domestic assets in commercial bank deposits, at interest rates linked to the Bank of Botswana certificate (Bob) rate, issued by the central bank to absorb excess domestic liquidity. The government has increased its local currency bond issuance in 2008 in order

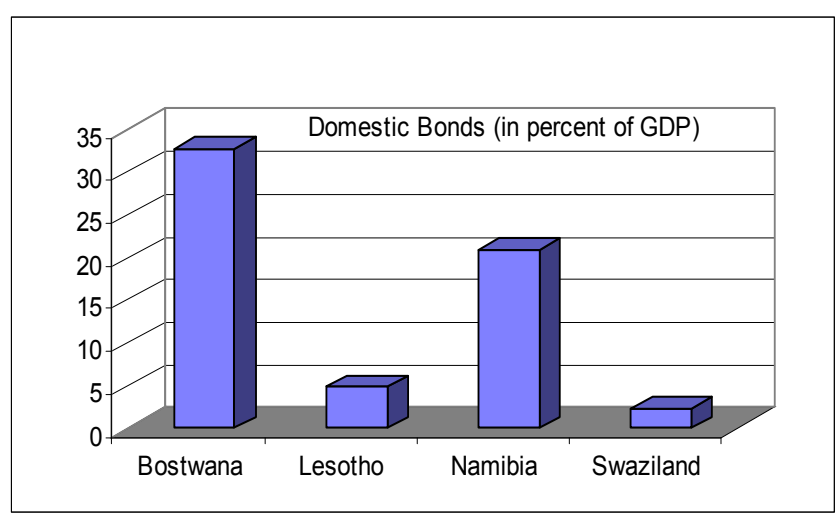
to provide alternative domestic investment vehicles for pension funds and allow the central bank to scale bank Bob issuance.

\section{As with pension funds, the insurance sector accumulates large amounts of} financial assets on average around $\mathbf{4 3}$ percent of GDP. In Namibia, the insurance sector is well developed but highly concentrated; there are 16 long-term insurers and 12 short-term insurers, but the top three in each segment account for more 85 percent of total premiums. The insurance market in Botswana, in spite of its small size, is considered to be a competitive one, highly exposed to the influence of the prevailing trends in the South African industry.

\footnotetext{
${ }^{7}$ Employees contribute 5 percent of their annual salary, while Government contributes 11.2 percent to the fund.

${ }^{8}$ Total income to the SNPF in the last four years are mainly from return on investment (70 percent) and the remainder from contributions.
} 
The total assets of Botswana's insurance companies amount to around 26 percent of GDP, with insurance contributions that are significantly higher than those for most other African countries. Lesotho has just one private insurance company, whose assets are about 15 percent of GDP; in Swaziland, there are five. Nonetheless, the market remains relatively small with a level of assets of no more than 4 percent as of end- 2007. Insurance companies in Botswana and Namibia have large foreign participation (above 90 percent), mostly, from South Africa. In addition, the market share is highly concentrated; the largest four to five companies comprise 82 percent of the assets.

\section{Saving and credit cooperatives and other deposit-taking institutions}

\section{There has been a rapid growth of SCCOs in all four countries to help provide} financial services to those without access to the banking sector. They primarily serve the financial services needs of their membership through savings and loan products. Indeed, the imposition of prohibitive fees on using bank services and the high cost of borrowing from the banking system have contributed in no small measure to the explosive growth of these saving societies. However, insufficient supervisory oversight and prudential regulation of the sector have resulted in governance issues and increasing member and client complaints, to include among others, lack of funds available at the SCCOs upon request.

\section{The importance of SCCOs in the financial system within the four countries} varies significantly. Total assets of Lesotho's credit cooperatives are about 7 percent of the total assets of the NBFIs, while Namibia's credit cooperatives share is negligible. In Botswana and Swaziland, the cooperatives have 5 and 3 percent of the total assets of the NBFIs respectively. For Swaziland that share is equivalent to about 4 percent of the banking system deposits. All credit cooperatives issue savings deposits that could be included in the definition of money aggregates. They mainly provide mortgage and construction loans to their members thus contributing to a social objective of providing housing. However, balance sheet information is not compiled and reported on a timely and periodic basis, and their activities are not overseen by the monetary authorities, but rather by government agencies.

25. Other NBFIs also play a role in providing financial services. The informal suppliers of funds in Botswana, Lesotho, Namibia and Swaziland are able to capitalize on the difficulties that people have in accessing the banking system. Among the many obstacles are high bank financial fees, lack of bank branches, unfamiliarity with the banking procedures, and difficulties in understanding the benefits of doing business with banks. Thus, traditional lenders and a whole range of microfinance institutions are important suppliers of funding for small businesses and individuals in rural and urban areas. However, they also tend to generally charge high up-front fees. Currently, supervision of these entities are lacking and are under non-financial entities (e.g., Ministry of Enterprise), hence data reporting is a major issue for assessing its significance. 


\section{Stock Exchanges}

\section{The stock exchanges in Botswana, Namibia and Swaziland are still relatively under developed and in some instance lack sufficient regulatory support. ${ }^{9}$ As such, its contribution to the development of the domestic private sector is considerably

\begin{tabular}{lrrrr} 
& \multicolumn{3}{c}{ Text Table 2 } \\
& $\begin{array}{l}\text { Botswana } \\
\text { Namibia }\end{array}$ & $\begin{array}{c}\text { Swaziland } \\
\text { Number of companies }\end{array}$ & S.Africa \\
\cline { 2 - 5 } Dual listing & 12 & 21 & 5 & 33 \\
Domestic listing & 19 & 9 & 1 & 389 \\
Total & 31 & 30 & 6 & 422 \\
\hline
\end{tabular}

limited. Most companies listed in the stock exchange of those countries are linked to major mining companies, and financial institutions headquartered in South Africa. The market capitalization of domestic companies is much smaller than the dual-listing. For example, in Botswana the domestic component is 5.4 percent of the foreign listing, while in Namibia the domestic market capitalization barely reaches 0.5 percent. The low level of the free-float ${ }^{10}$ in the stock exchanges of these countries also prevents potential participants to intervene in the market. Moreover, many institutional investors decide to buy and hold to maturity; thus, reducing even more the level of transactions and liquidity in the market.

Text Table 3.

\begin{tabular}{|c|c|c|c|c|c|c|c|}
\hline & \multicolumn{2}{|c|}{ Stock Market } & \multirow[t]{2}{*}{ T-bills } & \multirow[t]{2}{*}{ T-bonds } & \multirow{2}{*}{$\begin{array}{c}\text { C.Bank } \\
\text { Certificate }\end{array}$} & \multirow{2}{*}{$\begin{array}{c}\text { Total } \\
\text { Securities }\end{array}$} & \multirow{2}{*}{$\begin{array}{l}\text { Corporate } \\
\text { bond }\end{array}$} \\
\hline & Domestic & Dual-listing & & & & & \\
\hline & \multicolumn{7}{|c|}{ In percent of GDP } \\
\hline Bostwana & 41.4 & 710 & 9.0 & 0.75 & 23.0 & 32.7 & . \\
\hline Lesotho & - & 0 & 4.8 & $\ldots$ & $\ldots$ & 4.8 & $\ldots$ \\
\hline Namibia & 9.7 & 2,400 & 6.1 & 13.6 & 1.3 & 20.9 & 4.4 \\
\hline Swaziland & 8.1 & $\mathrm{n} / \mathrm{a}$ & 1.8 & 0.2 & 0.3 & 2.3 & $\ldots$ \\
\hline South Africa & 37.3 & $\mathrm{n} / \mathrm{a}$ & $\ldots$ & $\ldots$ & $\ldots$ & $\ldots$ & $\ldots$ \\
\hline
\end{tabular}

\section{Pension funds and}

insurance companies have the potential to contribute to the development of the securities market. This in turn requires the development of efficient trading and settlement systems, the adoption of modern accounting and auditing

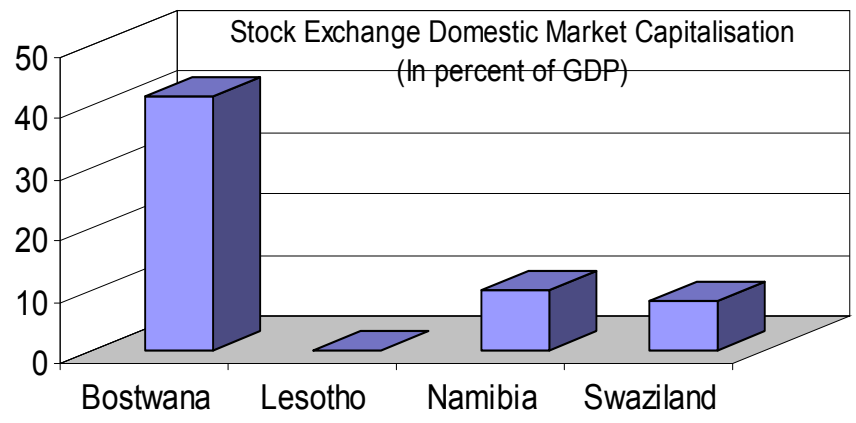
standards, and the promotion of information disclosure. Pension funds in particular can

${ }^{9}$ Lesotho does not have a stock exchange.

${ }^{10}$ The free float is considered the portion of the total shares that are ready to be exchanged on a public stock exchange through an initial public offering (or "flotation"). 
mobilize large, long-term and stable financial resources, and have the potential to completely transform the functioning of financial markets. However, the impact of pension funds and insurance companies on capital market efficiency depends on their size, their investment policies and their management practices.

28. All countries in the region have similar requirements for the pension funds and insurance companies to invest up to 35 percent of their assets in local markets; however, the effect on the measure differs across countries. Botswana sets a minimum of 30 percent domestic assets holding. These regulations are not likely to be effective since individuals remain free to invest directly in other CMA countries. In mature markets (Namibia and Botswana), there appears to be better investment opportunities (e.g., investing in cross listing, which allow local pension funds to invest in domestic branches of regional corporations, which are counted as domestic investments. ${ }^{11}$ In addition, their equity markets have a number of listed companies. In Swaziland, the situation is more precarious, since there are only 5 listed companies engaged in very little trading if any.

\section{NON BANK FINANCIAL INSTITUTIONS THE FINANCIAL SYSTEM AND THE REAL ECONOMY}

29. Similar to South Africa, the asset holdings of the NBFIs in Botswana, Lesotho, Namibia and Swaziland are much higher than that of the formal banking institutions. This relatively large holding of NBFIs motivates the need to analyze the link between the level of these assets and their role in the economic development of these countries. However, a shortage of data prevents a complete analysis of the role of these institutions. It is important to point out that although pension funds and insurance companies are the backbone of the NBFIs;

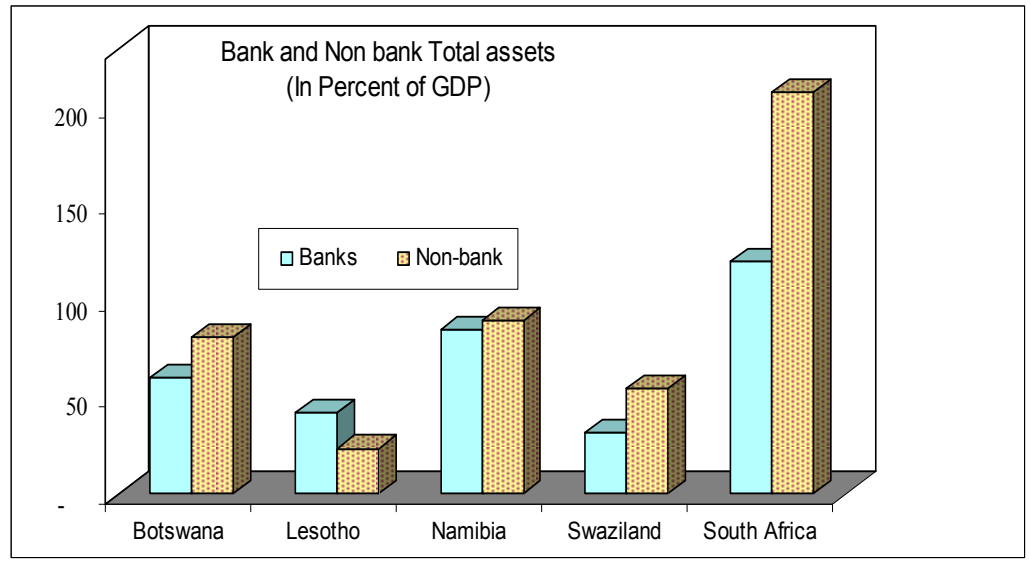
their financial transactions are mostly linked to investment abroad, with some residual impact on domestic economies, mainly because of a lack of domestic opportunities. In the case of

\footnotetext{
${ }^{11}$ Pension funds and insurance companies are required to invest in domestic market at least 35 percent of their total assets (government bonds, bank deposits, securities of domestic companies well as shares of foreign companies that are dual-listed on the Namibia Stock Exchange (NSX).
} 
SCCOs, with membership in the thousands, and given their level of assets they potentially can play a meaningful role in contributing to economic growth.

30. In at least one of the four countries, Swaziland, pension funds and other institutional investors compete directly with the financial sector with regards to lending. Faced with the domestic investment requirement of 30 percent, pension funds and insurance companies are lending directly to some industry participants, particularly the sugar and electricity sectors, at market rates. In all the four countries, investment opportunities also include investing in low-yielding government paper, in low-interest housing loans, and even in building low-rent housing units. The NBFIs inject liquidity into the local banking sector by keeping some assets invested in term-deposits (average return of 10 percent), rather than investment abroad. The benchmark rate of return is 5 percent in real terms. The large share of investments, however, continues to be in South Africa, where, over the last three years returns averaged about 9 percent. More recently, these returns have started to decline because of the slowdown of the South African economy.

\section{Banks and other specialist institutions like leasing and venture capital} companies could enhance NBFIs in the expansion of their financing role. Particularly with regards to the financing of smaller firms, pension funds and insurance companies rely on the formal banking system in channeling those resources, usually by increasing liquidity in the markets. As NBFIs reach critical mass, they are likely to help promote competition, stimulate financial innovation, improve financial information, strengthen corporate governance and encourage more robust regulation. The low level of personal wealth and the absence of a financial culture, including a dearth of financially skilled people, further limit the deepening and contribution of the financial sector towards economic development. It is therefore important to strike a balance between having a good record of financial performance and contributing towards deepening of the financial markets.

\section{NBFIs could play a more meaningful role in contributing to reducing poverty} through deepening of the financial sector, increasing access to finance, and lowering transaction costs. For a number of the rural poor, their only form of financing is only through microfinance institutions that may be organized at the local level. To the extent that financing from micro lenders assist in enabling the rural poor to engage in productive activities, this would have some impact on reducing poverty. Throughout Botswana, Lesotho, Namibia and Swaziland, small loans from micro lenders and in some instances SCCOs have been channeled into productive uses, particularly in support of subsistence agriculture.

\section{Conclusion}

\section{Despite the proliferation of NBFIs in Botswana, Lesotho, Namibia and}

Swaziland, financing is still very limited. The rapid growth of NBFIs in these countries reflects as much on the restrictive financial system as it does on the pervasive rural poverty and widespread unemployment. The challenge however remains to find a way to channel 
these resources to productive uses. Anecdotal evidence points to a very negligible impact on real growth within the countries under review, despite the high level of capitalization. Further development and proper regulation of NBFIs could however translate to tangible gains for these countries, since it has been shown that when financial development is sustainable, the credit market becomes more competitive and more efficient over time, and this could eventually contribute to economic growth.

\section{Pension funds and insurance companies with substantial financial resources} could help develop capital markets. However, these entities usually demand securities, which are normally in short supply. Limited liquidity is a major obstacle to the development of the stock market in Botswana, Namibia and Swaziland. In addition, the lack of attractive domestic investment opportunities has led to outflows of savings from these countries into the liquid and relatively well developed markets in neighboring South Africa. Access to such markets has benefited financial institution and individuals who are able to invest in a diversified range of products. Understanding the type of flows will help in designing policies to better manage these capital flows, allow higher interest rate and more attractive domestic investment opportunities could reduce such outflows.

\section{Effective supervision of the non-bank financial institutions in the countries} under review need further strengthening to allow an orderly expansion that could better serve the real sector needs. Failure to properly regulate the NBFI sector could result in serious consequences for participants. Already, in all the countries, complaints from clients are increasing as the under supervised SCCOs take advantage of the lax regulations. This worrisome trend also raises the distinct possibility that government may be forced to intervene to bail out these institutions, putting further pressure on the government budget.

\section{The current global financial crisis provides useful lessons on the importance of} an efficient regulatory and supervisory framework. However, regulation should be in line with economic structures and the stage of economic development. It should be designed to strike a balance between facilitating the long-term sustainability of the financial institutions and avoiding placing an undue burden on the regulatory body. At the same time, government must provide a sound economic environment, accompanied by structural reforms (improving the business climate, legal establishment, and governance) to provide stability to all players in the financial market, along with transparency and accountable institutions. 


\section{References}

A.M. Gulde, C. Patillo, J. Christensen, and others, Sub-Saharan Africa, Financial Sector Challenges, IMF, 2006.

Cameron R., 1967, Banking in The Early Stages of Industrialization: A Study in Comparative Economic History, Oxford University Press, New York, NY (1967).

D. Vittas, The Role of Non-Bank Financial intermediaries in Egypt and other MENA countries, Development Research Group, The world Bank, November 1997.

R. Cameron, Banking and Economic Development: Some Lessons of History, Oxford University Press, New York, NY (1972).

L. Deidda and B. Fattouh, Non-linearity between finance and growth, Economics Letters 74 (2002), pp. 339-345.

R. W. Goldsmith, Financial Structure and Development New Haven: Yale University Press (1969).

R.D.F. Harris, Stock market and development: a re-assessment, European Economic Review 41 (1997), pp. 139-146.

R.G. King and R. Levine, Finance and growth: Schumpeter might be right, Quarterly Journal

of Economics 109 (1993), pp. 717-737.

R. Levine, Financial development and economic growth: views and agenda, Journal of Economic Literature 35 (1997), pp. 688-726.

R.G. King and R. Levine, Finance, entrepreneurship, and growth theory and evidence, Journal of Monetary Economics 32 (1993), pp. 513-542.

R.I. McKinnon, Financial liberalization and economic development: reassessment of interest rate policies in Asia and Latin America, Oxford Review of Economic Policy 4 (1989), pp.34-56.

E. S. Shaw, Financial Deepening in Economic Development New York: Oxford University Press (1973).

Z. Xu, Financial development, investment, and economic growth, Economic Enquiry 38 (2000), pp. 331-344. 
Bank of Botswana, Annual Report.

Bank of Namibia, Annual Report.

Botswana Stock Exchange Annual Report.

Central Bank of Swaziland, Annual Report.

Namibia Stock exchange Annual Report.

Swaziland Stock Exchange Annual Report. 
Statistical APPEndix TABles

Table 1. Swaziland: Gross Domestic Product by Sector of Origin at 2000 Constant Prices, 2003-07

\begin{tabular}{|c|c|c|c|c|c|}
\hline & 2003 & 2004 & 2005 & 2006 & 2007 \\
\hline & \multicolumn{4}{|c|}{ (In millions of emalangeni) } & \\
\hline Primary production & $1,169.2$ & $1,146.3$ & $1,197.8$ & $1,173.9$ & $1,197.9$ \\
\hline Agriculture and livestock & $1,072.7$ & $1,042.1$ & $1,098.1$ & $1,073.8$ & $1,102.6$ \\
\hline SNL crops $1 /$ & 65.1 & 76.1 & 75.7 & 64.7 & 70.4 \\
\hline TDL crops 2/ & 909.2 & 890.4 & 930.7 & 916.7 & 867.6 \\
\hline Livestock and other & 98.4 & 75.6 & 91.7 & 93.0 & 84.3 \\
\hline Forestry & 67.3 & 72.5 & 74.9 & 71.3 & 80.4 \\
\hline Mining & 29.1 & 31.8 & 24.9 & 28.8 & 14.9 \\
\hline Secondary production & $4,146.6$ & $4,170.4$ & $4,145.6$ & $4,243.8$ & $4,353.4$ \\
\hline Manufacturing & $3,526.7$ & $3,566.1$ & $3,600.0$ & $3,677.0$ & $3,787.8$ \\
\hline Electricity and water & 133.0 & 129.6 & 134.3 & 141.1 & 154.3 \\
\hline Construction & 487.0 & 474.7 & 411.3 & 425.7 & 411.3 \\
\hline Services & $3,960.2$ & $4,193.1$ & $4,382.1$ & $4,589.4$ & $4,796.3$ \\
\hline Wholesale and retail & 579.9 & 638.6 & 689.2 & 766.4 & 843.5 \\
\hline Hotels and restaurants & 174.4 & 180.1 & 196.9 & 212.5 & 228.2 \\
\hline Transport & 354.0 & 374.0 & 389.6 & 372.0 & 378.9 \\
\hline Communications & 395.2 & 493.6 & 561.4 & 589.8 & 602.3 \\
\hline Banking, finance, and insurance & 390.7 & 394.3 & 399.1 & 423.2 & 430.1 \\
\hline Real estate & 434.7 & 446.3 & 456.7 & 470.9 & 490.3 \\
\hline Government services & $1,382.1$ & $1,426.8$ & $1,446.8$ & $1,512.5$ & $1,578.8$ \\
\hline Other services & 166.1 & 169.4 & 173.3 & 177.5 & 184.0 \\
\hline Owner-occupied dwellings & 297.7 & 291.7 & 297.4 & 302.6 & 309.8 \\
\hline Imputed bank service charge & -214.5 & -221.7 & -228.3 & -238.0 & -249.6 \\
\hline GDP at factor cost & $9,276.0$ & $9,509.9$ & $9,725.5$ & $10,007.2$ & $10,347.6$ \\
\hline Indirect taxes less subsidies & $1,935.3$ & $1,976.8$ & $2,008.1$ & $2,066.7$ & $2,146.0$ \\
\hline \multirow[t]{2}{*}{ GDP at market prices $3 /$} & $11,211.3$ & $11,486.6$ & $11,733.7$ & $12,073.9$ & $12,493.6$ \\
\hline & \multicolumn{4}{|c|}{ (Annual percentage change) } & \\
\hline Agriculture and livestock & 4.9 & -2.9 & 5.4 & -2.2 & 2.7 \\
\hline Forestry & 2.8 & 7.7 & 3.3 & -4.8 & 12.8 \\
\hline Mining & -20.1 & 9.0 & -21.6 & 15.8 & -48.3 \\
\hline Manufacturing & 1.9 & 1.1 & 0.9 & 2.1 & 3.0 \\
\hline Electricity and water & 2.5 & -2.5 & 3.6 & 5.1 & 9.3 \\
\hline Construction & 35.4 & -2.5 & -13.3 & 3.5 & -3.4 \\
\hline Services & 2.7 & 5.9 & 4.5 & 4.7 & 4.5 \\
\hline \multirow[t]{2}{*}{ GDP at market prices } & 3.9 & 2.5 & 2.2 & 2.9 & 3.5 \\
\hline & \multicolumn{4}{|c|}{ (In percent of GDP at factor cost) } & \\
\hline Agriculture and livestock & 11.6 & 11.0 & 11.3 & 10.7 & 10.7 \\
\hline Forestry & 0.7 & 0.8 & 0.8 & 0.7 & 0.8 \\
\hline Mining & 0.3 & 0.3 & 0.3 & 0.3 & 0.1 \\
\hline Manufacturing & 38.0 & 37.5 & 37.0 & 36.7 & 36.6 \\
\hline Electricity and water & 1.4 & 1.4 & 1.4 & 1.4 & 1.5 \\
\hline Construction & 5.2 & 5.0 & 4.2 & 4.3 & 4.0 \\
\hline Services & 42.7 & 44.1 & 45.1 & 45.9 & 46.4 \\
\hline
\end{tabular}

Source: Central Statistical Office.

1/ Swazi Nation Land (SNL).

2/ Title Deed Land (TDL).

3/ Under review by the CSO; data on indirect taxes used for estimation of GDP may contain errors and are subject to downward revisions based on 
Table 2. Swaziland: Gross Domestic Product by Sector of Origin at Current Prices, 2003-07 (In millions of emalangeni, unless otherwise indicated)

\begin{tabular}{|c|c|c|c|c|c|}
\hline & 2003 & 2004 & 2005 & 2006 & 2007 \\
\hline Primary production & $1,123.9$ & $1,140.7$ & $1,184.8$ & $1,209.9$ & $1,337.7$ \\
\hline Agriculture and livestock & 993.1 & 997.2 & $1,038.7$ & $1,041.2$ & $1,155.8$ \\
\hline SNL crops $1 /$ & 74.1 & 101.6 & 102.3 & 87.8 & 108.0 \\
\hline TDL crops 2/ & 838.6 & 813.5 & 859.0 & 865.4 & 951.9 \\
\hline Livestock and other & 80.4 & 82.1 & 77.4 & 88.0 & 95.9 \\
\hline Forestry & 80.4 & 86.5 & 101.9 & 112.1 & 121.5 \\
\hline Mining & 50.4 & 57.0 & 44.2 & 56.6 & 60.4 \\
\hline Secondary production & $5,325.1$ & $5,600.6$ & $6,058.6$ & $7,359.4$ & $8,532.2$ \\
\hline Manufacturing & $4,577.6$ & $4,820.2$ & $5,349.4$ & $6,623.7$ & $7,717.1$ \\
\hline Electricity and water & 108.0 & 124.6 & 132.1 & 138.9 & 148.8 \\
\hline Construction & 639.6 & 655.8 & 577.1 & 596.8 & 666.3 \\
\hline Services & $4,851.2$ & $5,375.0$ & $6,130.5$ & $6,710.2$ & $7,530.2$ \\
\hline Wholesale and retail & 669.2 & 813.5 & 934.1 & $1,064.0$ & $1,153.5$ \\
\hline Hotels and restaurants & 205.5 & 206.9 & 214.7 & 268.1 & 330.2 \\
\hline Transport & 374.8 & 396.8 & 430.6 & 401.7 & 431.6 \\
\hline Communications & 532.6 & 607.6 & 662.7 & 736.0 & 812.0 \\
\hline Banking, finance, and insurance & 314.2 & 382.4 & 443.6 & 491.6 & 540.8 \\
\hline Real estate & 523.9 & 559.3 & 606.9 & 646.7 & 707.3 \\
\hline Government services & $2,003.0$ & $2,207.8$ & $2,648.8$ & $2,926.8$ & $3,395.0$ \\
\hline Other services & 214.9 & 226.5 & 245.7 & 255.1 & 266.5 \\
\hline Owner-occupied dwellings & 225.4 & 232.7 & 243.1 & 252.3 & 258.6 \\
\hline Imputed bank service charge & -212.3 & -258.4 & -299.7 & -332.1 & -365.3 \\
\hline GDP at factor cost & $11,300.2$ & $12,116.4$ & $13,373.9$ & $15,279.4$ & $17,400.1$ \\
\hline Indirect taxes less subsidies & $2,474.4$ & $2,622.3$ & $2,676.1$ & $2,798.4$ & $2,986.3$ \\
\hline GDP at market prices $3 /$ & $13,774.6$ & $14,738.7$ & $16,050.0$ & $18,077.8$ & $20,386.4$ \\
\hline \multicolumn{6}{|l|}{ Memorandum items: } \\
\hline GDP deflator (index, $2000=100$ ) & 122.9 & 128.3 & 136.8 & 149.7 & 163.2 \\
\hline (percent change) & 5.9 & 4.4 & 6.6 & 9.5 & 9.0 \\
\hline \multicolumn{6}{|l|}{ Source: Central Statistical Office. } \\
\hline \multicolumn{6}{|l|}{ 1/ Swazi Nation Land (SNL). } \\
\hline $\begin{array}{l}\text { 2/ Title Deed Land (TDL). } \\
\text { 3/ Under review by the CSC } \\
\text { and are subject to downwar }\end{array}$ & & & & & \\
\hline
\end{tabular}


Table 3. Swaziland: Gross Domestic Product by Expenditure Category at Current Prices, 2003-07

\begin{tabular}{|c|c|c|c|c|c|}
\hline & 2003 & 2004 & 2005 & 2006 & 2007 \\
\hline & \multicolumn{5}{|c|}{ (In millions of emalangeni) } \\
\hline Final consumption expenditure & $10,903.5$ & $12,146.8$ & $15,473.0$ & $17,381.9$ & $19,182.4$ \\
\hline Private & $8,222.4$ & $8,724.1$ & $12,024.0$ & $13,604.6$ & $15,042.6$ \\
\hline Government & $2,681.0$ & $3,422.6$ & $3,449.1$ & $3,777.3$ & $4,139.8$ \\
\hline Capital formation & $2,590.4$ & $2,831.6$ & $2,983.3$ & $3,012.2$ & $3,310.3$ \\
\hline Gross fixed capital formation & $2,590.4$ & $2,831.6$ & $2,983.3$ & $3,011.2$ & $3,308.3$ \\
\hline Private & $1,772.6$ & $1,572.6$ & $1,573.6$ & $1,574.6$ & $1,575.6$ \\
\hline Public & 817.8 & $1,259.0$ & $1,409.7$ & $1,436.6$ & $1,732.7$ \\
\hline Increases in stocks & 0.0 & 0.0 & 0.0 & 1.0 & 2.0 \\
\hline Balance of trade for goods and nonfactor serv & 280.8 & -239.7 & $-2,406.4$ & $-2,316.3$ & $-2,106.3$ \\
\hline Exports & $11,953.9$ & $13,279.8$ & $12,204.1$ & $13,178.5$ & $15,667.3$ \\
\hline Imports, f.o.b. ${ }^{1}$ & $-11,673.1$ & $-13,519.5$ & $-14,610.5$ & $-15,494.8$ & $-17,773.6$ \\
\hline \multirow[t]{2}{*}{ GDP at market prices ${ }^{2}$} & $13,774.6$ & $14,738.7$ & $16,050.0$ & $18,077.8$ & $20,386.4$ \\
\hline & \multicolumn{5}{|c|}{ (In percent of GDP) } \\
\hline Final consumption expenditure & 79.2 & 82.4 & 96.4 & 96.2 & 94.1 \\
\hline Private & 59.7 & 59.2 & 74.9 & 75.3 & 73.8 \\
\hline Government & 19.5 & 23.2 & 21.5 & 20.9 & 20.3 \\
\hline Capital formation & 18.8 & 19.2 & 18.6 & 16.7 & 16.2 \\
\hline Gross fixed capital formation & 18.8 & 19.2 & 18.6 & 16.7 & 16.2 \\
\hline Public & 12.9 & 10.7 & 9.8 & 8.7 & 7.7 \\
\hline Private & 5.9 & 8.5 & 8.8 & 7.9 & 8.5 \\
\hline Increases in stocks & 0.0 & 0.0 & 0.0 & 0.0 & 0.0 \\
\hline Balance of trade for goods and nonfactor serv & 2.0 & -1.6 & -15.0 & -12.8 & -10.3 \\
\hline Exports of goods and services & 86.8 & 90.1 & 76.0 & 72.9 & 76.9 \\
\hline Imports of goods and services, f.o.b. & -84.7 & -91.7 & -91.0 & -85.7 & -87.2 \\
\hline GDP at market prices & 100.0 & 100.0 & 100.0 & 100.0 & 100.0 \\
\hline
\end{tabular}

Source: Central Statistical Office.

${ }^{1}$ All Southern African Customs Union receipts are treated as indirect taxes (and therefore deducted from imports, c.i.f. to get imports, f.o.b.), accounting for the significant difference between the trade figures in the national income accounts reported in this table and those in the balance of payments.

${ }^{2}$ Under review by the CSO; data on indirect taxes used for estimation of

GDP may contain errors and are subject to downward revisions based on the review. 
Table 4. Swaziland: Population and Labor Force Estimates, 2002-07

\begin{tabular}{|c|c|c|c|c|c|c|}
\hline & 2002 & 2003 & 2004 & 2005 & 2006 & 2007 \\
\hline Annual population growth ${ }^{1}$ & 0.37 & 0.36 & 0.36 & 0.37 & 0.37 & 0.37 \\
\hline Population (in thousands) ${ }^{1}$ & 999.4 & $1,003.2$ & 1006.9 & 1010.8 & 1014.6 & 1018.4 \\
\hline Population density (per sq.km.) & 57.5 & 57.8 & 58.0 & 58.2 & 58.4 & 58.6 \\
\hline Labor force ${ }^{2}$ & 314.9 & 319.1 & 322.3 & 331.8 & 337.2 & $\ldots$ \\
\hline Total employment $^{3}$ & 113.0 & 114.0 & 114.8 & 115.9 & 115.4 & $\ldots$ \\
\hline Formal employment & 92.2 & 92.6 & 93.1 & 93.4 & 92.1 & $\ldots$ \\
\hline Public sector & 29.3 & 27.4 & 27.8 & 28.0 & 27.5 & $\ldots$ \\
\hline Private sector & 62.9 & 65.2 & 65.3 & 65.4 & 64.6 & $\ldots$ \\
\hline Informal employment & 20.8 & 21.4 & 21.7 & 22.5 & 23.3 & $\ldots$ \\
\hline Unemployment rate (in percent) & 30.0 & 29.0 & 30.0 & 30.0 & 30.0 & $\ldots$ \\
\hline
\end{tabular}

Sources: Sources: World Bank's World Development Indicators; and staff estimates.

${ }^{1}$ National authorities, World Bank and staff estimates

${ }^{2}$ World Bank estimates.

${ }^{3}$ Ministry of Enterprise and Employment. 
Table 5. Swaziland: Developments in Crop Production, 2002/03-2006/07 ${ }^{1}$

\begin{tabular}{|c|c|c|c|c|c|}
\hline & $2002 / 03$ & $2003 / 04$ & $2004 / 05$ & $2005 / 06$ & $2006 / 07$ \\
\hline & \multicolumn{5}{|c|}{ (In thousands of metric tons) } \\
\hline \multicolumn{6}{|l|}{ Volume } \\
\hline Sugarcane & 4,609 & 5,046 & 4,884 & 5,144 & 4,931 \\
\hline Cotton & 3.5 & 2.8 & 5.0 & 0.9 & $\ldots$ \\
\hline Maize & 62.5 & 71 & 75 & 67.1 & 69.2 \\
\hline $\mathrm{SNL}^{2}$ & 57.5 & 65.3 & 69.0 & 61.7 & 63.7 \\
\hline $\mathrm{TDL}^{3}$ & 5.0 & 5.7 & 6.0 & 5.4 & 5.5 \\
\hline Citrus fruit & 74.4 & 70.9 & 67.1 & 70.5 & 70.8 \\
\hline Tobacco & $\cdots$ & $\cdots$ & $\cdots$ & $\cdots$ & $\ldots$ \\
\hline & \multicolumn{5}{|c|}{ (In metric tons per hectare) } \\
\hline \multicolumn{6}{|l|}{ Yield } \\
\hline Sugarcane & 102.0 & 105.0 & 98.0 & 101.9 & 97.8 \\
\hline Cotton & 348.9 & $\ldots$ & & $\ldots$ & \\
\hline Maize & & & & $\ldots$ & \\
\hline $\mathrm{SNL}^{2}$ & $\ldots$ & $\ldots$ & $\ldots$ & $\ldots$ & $\ldots$ \\
\hline $\mathrm{TDL}^{3}$ & $\ldots$ & $\ldots$ & $\ldots$ & $\ldots$ & $\ldots$ \\
\hline Citrus fruit & $\ldots$ & $\ldots$ & $\ldots$ & $\ldots$ & $\ldots$ \\
\hline & \multicolumn{5}{|c|}{ (In millions of emalangeni) } \\
\hline \multicolumn{6}{|l|}{ Value } \\
\hline Sugarcane & $\ldots$ & $\ldots$ & & $\ldots$ & $\ldots$ \\
\hline Cotton & 8.6 & 6.9 & 12.3 & 2.2 & $\ldots$ \\
\hline Maize & 47.6 & 54.1 & 57.2 & 51.1 & 52.8 \\
\hline $\mathrm{SNL}^{2}$ & 42.9 & 48.7 & 51.4 & 46.0 & 47.5 \\
\hline $\mathrm{TDL}^{3}$ & 4.8 & 5.4 & 5.7 & 5.1 & 5.3 \\
\hline Citrus fruit & 122.2 & 99.8 & 97.8 & 95.8 & 116.6 \\
\hline
\end{tabular}

Source: Central Statistical Office and Swaziland Sugar Association.

${ }^{1}$ Variable crop years.

${ }^{2}$ Swazi Nation Land (SNL).

${ }^{3}$ Title Deed Land (TDL). 
Table 6. Developments in Sugar Production, Processing, and Consumption, 2002/03-2006/07

2002/03 2003/04 2004/05 2005/06 2006/07

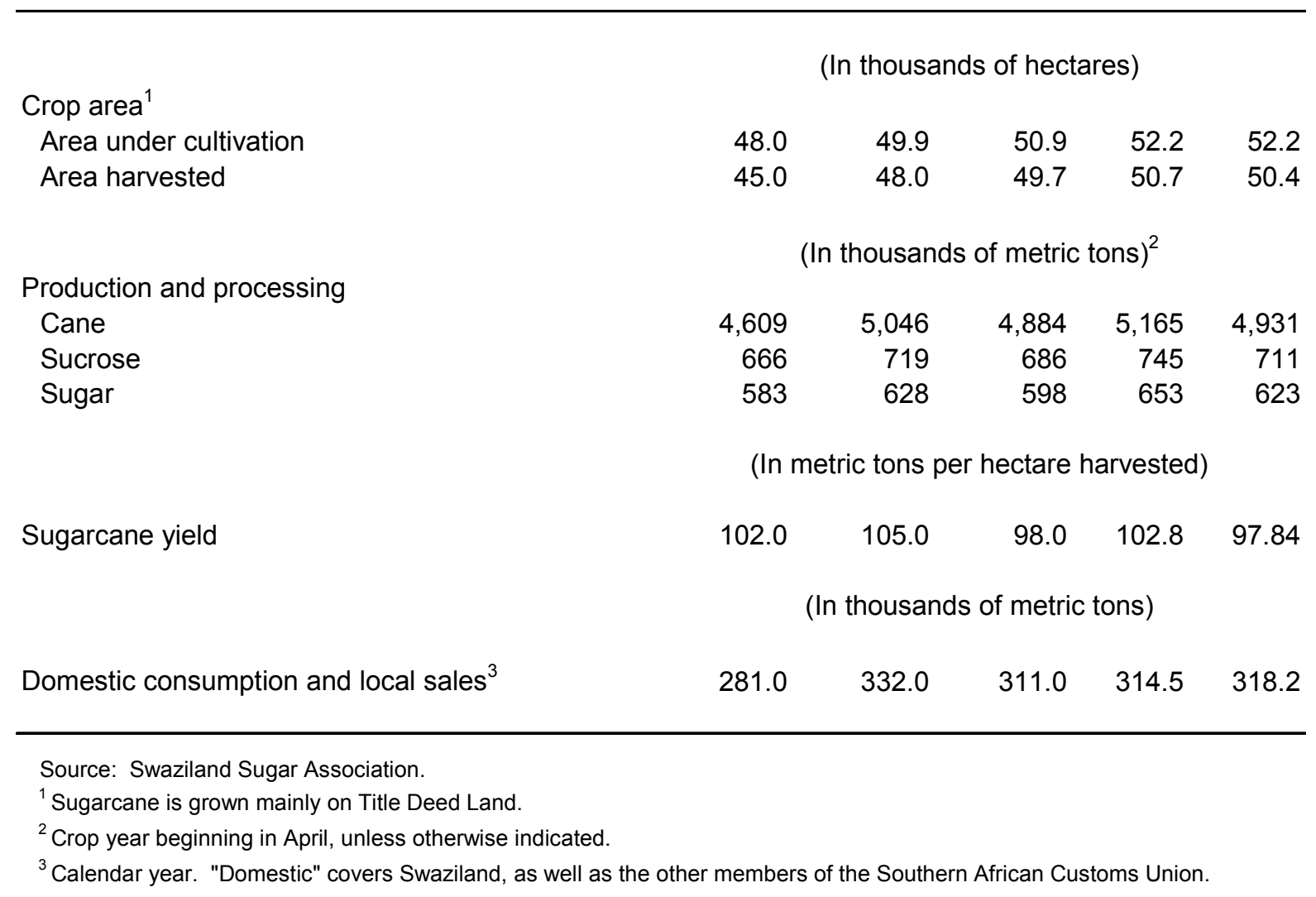


Table 7. Swaziland: Mineral Production and Exports, 2001-06

\begin{tabular}{|c|c|c|c|c|c|c|}
\hline & 2001 & 2002 & 2003 & 2004 & 2005 & 2006 \\
\hline & \multicolumn{6}{|c|}{ (In thousands of metric tons) } \\
\hline \multicolumn{7}{|l|}{ Production } \\
\hline Quarried stone $\left(\mathrm{M}^{3}\right)$ & $\ldots$ & $\ldots$ & $\ldots$ & 230.1 & 566.8 & 534.7 \\
\hline Coal & 313.0 & $\begin{array}{l}553.4 \\
\text { (In the }\end{array}$ & $\begin{array}{l}448.7 \\
\text { inds of }\end{array}$ & $\begin{array}{l}488.3 \\
\text { langeni) }\end{array}$ & 221.7 & 310.6 \\
\hline Exports & & & & & & \\
\hline Quarried stone & $\ldots$ & $\ldots$ & $\ldots$ & 12.4 & 15.3 & 18.4 \\
\hline Coal & 54.9 & 97.1 & 78.7 & 85.7 & 47.5 & 90.4 \\
\hline
\end{tabular}

Sources: Central Bank of Swaziland; and Geological Survey and Mines Department. 
Table 8. Swaziland: Electrical Power Generation and Demand, 2001-05

\begin{tabular}{|c|c|c|c|c|c|}
\hline & 2001 & 2002 & 2003 & 2004 & 2005 \\
\hline Total local production and imports ${ }^{1}$ & 846.9 & 893.0 & 994.1 & $1,020.3$ & 828.2 \\
\hline Local production ${ }^{2}$ & 205.6 & 203.7 & 123.0 & 103.5 & 159.5 \\
\hline Hydroelectric & 243.9 & 202.2 & 121.6 & $\ldots$ & 159.5 \\
\hline Diesel & 1.7 & 1.5 & 1.4 & $\ldots$ & $\ldots$ \\
\hline Imports (from ESKOM + STEM \& EDM) ${ }^{3}$ & 601.3 & 689.3 & 871.1 & 916.8 & 668.7 \\
\hline Total sales ${ }^{1}$ & 719.5 & 764.6 & 831.8 & 836.4 & 868 \\
\hline Household & 170.8 & 177.8 & 189.1 & 190.6 & 207.9 \\
\hline Commercial & 74.9 & 80.7 & 87.4 & 91.5 & 92.9 \\
\hline Irrigation power and bulk & 473.8 & 506.1 & 555.3 & 558.7 & 543.1 \\
\hline
\end{tabular}


Table 9. Swaziland: Retail Price Indices of Urban Families, 2003-08 ${ }^{1}$

\begin{tabular}{|c|c|c|c|c|c|c|}
\hline & 2003 & 2004 & 2005 & 2006 & 2007 & $\begin{array}{r}2008 \\
\text { July } \\
\end{array}$ \\
\hline & \multicolumn{6}{|c|}{ (April $2007=100)$} \\
\hline All-groups index ${ }^{2}$ & 82.0 & 84.6 & 90.0 & 94.9 & 106.9 & 116.9 \\
\hline Food \& Non Alcoholic beverages & 63.8 & 67.5 & 77.1 & 89.7 & 112.2 & 125.9 \\
\hline Alcoholic beverages \& Tobacco & 75.7 & 80.3 & 87.1 & 96.5 & 101.5 & 110.0 \\
\hline Clothing an Footwear & 102.9 & 103.6 & 104.4 & 101.7 & 100.0 & 102.4 \\
\hline Housing $^{3}$ & 92.8 & 97.6 & 98.8 & 100.0 & & \\
\hline Housing, water, electricity, gas \&other fuels & 91.1 & 95.3 & 98.9 & 100.1 & 99.6 & 113.9 \\
\hline Furnishings, households equipment and maintenance & 101.4 & 100.7 & 99.5 & 98.2 & 103.5 & 109.8 \\
\hline Household operations ${ }^{3}$ & 93.1 & 95.9 & 96.6 & 99.2 & 100.0 & 100.0 \\
\hline Health & 99.0 & 98.4 & 99.2 & 100.3 & 106.3 & 106.3 \\
\hline Transport & 85.5 & 87.3 & 95.9 & 97.0 & 115.5 & 134.2 \\
\hline Communications & & & & & 93.4 & 105.2 \\
\hline Recreation and Culture & 103.4 & 102.5 & 98.0 & 98.2 & 102.2 & 104.1 \\
\hline Education & 74.9 & 76.7 & 86.2 & 88.7 & 100.7 & 101.2 \\
\hline Personal Care ${ }^{3}$ & 99.4 & 100.1 & 99.7 & 100.4 & 100.0 & 100.0 \\
\hline Restaurants and hotels & & & & & 107.3 & 118.2 \\
\hline Miscellaneous of goods and services & 99.2 & 99.5 & 99.2 & 99.3 & 103.8 & 108.3 \\
\hline Low-income index ${ }^{4}$ & 193.3 & 201.3 & $\ldots$ & 237.22 & $\cdots$ &.. \\
\hline \multirow[t]{2}{*}{ Middle- and high-income index5 } & 179.2 & 185.0 & $\ldots$ & 206.79 & $\ldots$ & $\cdots$ \\
\hline & \multicolumn{6}{|c|}{ (Percentage change over previous year) } \\
\hline All-groups index ${ }^{2}$ & 4.6 & 3.2 & 6.3 & 5.5 & 12.6 & 13.3 \\
\hline Low-income index ${ }^{4}$ & 4.8 & 4.1 & $\ldots$ & $\ldots$ & $\ldots$ & $\ldots$ \\
\hline Middle- and high-income index ${ }^{5}$ & 4.7 & 3.2 & $\cdots$ & $\cdots$ & $\cdots$ & $\cdots$ \\
\hline \multicolumn{7}{|l|}{ Memorandum item: } \\
\hline Consumer price index in South Africa (e-o-p) & 0.3 & 3.5 & 3.6 & 5.8 & 9.0 & 12.2 \\
\hline
\end{tabular}

Source: Central Statistical Office.

${ }^{1}$ CPI figures based on a new base year (April 2007=100); revised basket of food and services, and weights.

${ }^{2}$ End of period; derived by splicing and applying the monthly changes to the old series.

${ }^{3}$ These items were merged into different categories beginning in May 2007.

${ }^{4}$ End of period; families with incomes of E 2,399 per annum and below.

${ }^{5}$ End of period; families with incomes between $E$ 2,400 and E 8,760 per annum. 
Table 10. Swaziland: Minimum Wages for General Workers in Selected Industries, 2002-06 ${ }^{1}$

\begin{tabular}{|c|c|c|c|c|c|}
\hline & 2002 & 2003 & 2004 & 2005 & 2006 \\
\hline \multicolumn{6}{|l|}{ Retail and wholesale } \\
\hline Mbabane and Manzini & 833.0 & 833.0 & 833.0 & 833.0 & 833.0 \\
\hline Elsewhere & 726.6 & 726.6 & 726.6 & 726.6 & 726.6 \\
\hline Manufacturing and processing & 131.1 & 131.1 & 131.1 & 131.1 & 131.1 \\
\hline Agriculture & 12.8 & 12.8 & 12.8 & 12.8 & 12.8 \\
\hline Building and construction & 4.1 & 4.1 & 4.1 & 4.1 & 4.1 \\
\hline Motor and engineering trades & 3.3 & 3.3 & 3.3 & 3.3 & 3.3 \\
\hline \multicolumn{6}{|l|}{ Retail and wholesale } \\
\hline Mbabane and Manzini & 0.0 & 0.0 & 0.0 & 0.0 & 0.0 \\
\hline Elsewhere & 0.0 & 0.0 & 0.0 & 0.0 & 0.0 \\
\hline Manufacturing and processing & 9.0 & 0.0 & 0.0 & 0.0 & 0.0 \\
\hline Agriculture & 0.0 & 0.0 & 0.0 & 0.0 & 0.0 \\
\hline Building and construction & 0.0 & 0.0 & 0.0 & 0.0 & 0.0 \\
\hline Motor and engineering trades & 0.0 & 0.0 & 0.0 & 0.0 & 0.0 \\
\hline
\end{tabular}

Source: Department of Labor.

${ }^{1}$ As of December of each year. 
Table 11. Swaziland: Paid Employment in the Private and Public Sectors by Industry, 2002-05 ${ }^{1}$

\begin{tabular}{|c|c|c|c|c|c|c|c|c|}
\hline & \multicolumn{2}{|c|}{2002} & \multicolumn{2}{|c|}{2003} & \multicolumn{2}{|c|}{2004} & \multicolumn{2}{|c|}{2005} \\
\hline & Private & Public & Private & Public & Private & Public & Private & Public \\
\hline Agriculture/forestry & 18,072 & 1,261 & 19,979 & 1,512 & 19,042 & 1,762 & 18,345 & 1,610 \\
\hline Mining and quarrying & 953 & 0 & 1,153 & 0 & 1,407 & 0 & 1,283 & 0 \\
\hline Manufacturing & 19,485 & 0 & 19,485 & 0 & 19,874 & 0 & 20,272 & 0 \\
\hline Electricity and water & 0 & 1,447 & 0 & 1,418 & 0 & 1,389 & & 859 \\
\hline Construction & 3,667 & 689 & 3,740 & 1,084 & 3,815 & 1,478 & 3,891 & 1,224 \\
\hline Distribution & 10,453 & 0 & 9,021 & 0 & 9,988 & 0 & 11,454 & 0 \\
\hline Transportation & 1,031 & 1,685 & 1,312 & 1,179 & 1,593 & 672 & 1,680 & 1,327 \\
\hline Finance & 6,546 & 1,095 & 5,508 & 914 & 4,470 & 732 & 5,583 & 847 \\
\hline Social services & 5,010 & 21,258 & 5,098 & 21,660 & 5,185 & 22,062 & 5,613 & 21,615 \\
\hline Total & 65,217 & 27,435 & 65,296 & 27,767 & 65,374 & 28,095 & 68,121 & 27,482 \\
\hline
\end{tabular}

Source: Ministry of Enterprise and Employment.

${ }^{1}$ Paid employment (including part-time) as of June of each year. 
Table 12. Swaziland: Summary of Central Government Operations, 2003/04-2007/08

\begin{tabular}{|c|c|c|c|c|c|}
\hline & $2003 / 04$ & $2004 / 05$ & $2005 / 06$ & $2006 / 07$ & $2007 / 08$ \\
\hline & \multicolumn{5}{|c|}{ (In millions of emalangeni) } \\
\hline Total revenue and grants & $3,908.4$ & $4,841.8$ & $5,499.1$ & $8,020.6$ & $8,341.1$ \\
\hline Tax revenue & $3,660.5$ & $4,627.8$ & $5,189.5$ & $7,682.8$ & $7,564.9$ \\
\hline SACU receipts & $1,878.1$ & $2,772.8$ & $3,101.1$ & $5,321.8$ & $4,989.9$ \\
\hline Non-SACU revenue & $1,782.4$ & $1,855.0$ & $2,088.4$ & $2,361.0$ & $2,575.0$ \\
\hline Nontax revenue & 110.2 & 98.0 & 137.3 & 172.1 & 713.5 \\
\hline Total expenditure and net lending & $4,314.0$ & $5,557.0$ & $5,757.7$ & $6,062.7$ & $6,992.9$ \\
\hline Current expenditure & $3,437.2$ & $4,295.0$ & $4,416.3$ & $4,681.3$ & $5,217.3$ \\
\hline Wages and salaries & $1,668.9$ & $1,964.0$ & $2,443.0$ & $2,588.7$ & $2,750.2$ \\
\hline Goods and services & $1,003.0$ & $1,421.0$ & 995.8 & $1,202.8$ & $1,343.0$ \\
\hline Interest payments & 173.8 & 168.0 & 194.4 & 163.4 & 211.3 \\
\hline Subsidies and transfers & 591.5 & 742.0 & 783.1 & 726.4 & 912.8 \\
\hline Capital expenditure & 817.8 & $1,259.0$ & $1,409.7$ & $1,436.6$ & $1,732.7$ \\
\hline Net lending & 59.0 & 3.0 & -68.3 & -55.2 & 43.0 \\
\hline Primary balance & -231.8 & -547.2 & -64.2 & $2,121.3$ & $1,559.5$ \\
\hline Overall balance (including grants) & -405.6 & -715.2 & -258.7 & $1,957.9$ & $1,348.2$ \\
\hline Overall balance (excluding grants) & -543.3 & -831.2 & -430.9 & $1,792.2$ & $1,285.4$ \\
\hline Financing & 405.6 & 715.2 & 258.7 & $-1,957.9$ & $-1,348.2$ \\
\hline Foreign (net) & 77.0 & 255.0 & 211.5 & $-1,090.0$ & -756.9 \\
\hline Domestic (net) $2 /$ & 328.6 & 460.3 & 47.1 & -867.9 & $-1,446.2$ \\
\hline Government debt & $2,852.1$ & $2,800.7$ & $2,729.9$ & $3,251.7$ & $3,940.1$ \\
\hline Foreign & $2,488.7$ & $2,293.3$ & $2,303.0$ & $2,742.3$ & $3,500.1$ \\
\hline \multirow[t]{2}{*}{ Domestic } & 363.5 & 507.4 & 426.9 & 509.4 & 440.0 \\
\hline & \multicolumn{5}{|c|}{ (In percent of GDP, unless otherwise specified) } \\
\hline Total revenue and grants & 27.6 & 30.9 & 32.0 & 43.0 & 39.7 \\
\hline Tax revenue & 25.8 & 29.5 & 30.2 & 41.2 & 36.0 \\
\hline SACU receipts & 13.3 & 17.7 & 18.1 & 28.5 & 23.8 \\
\hline Non-SACU revenue & 12.6 & 11.8 & 12.2 & 12.7 & 12.3 \\
\hline Nontax revenue & 0.8 & 0.6 & 0.8 & 0.9 & 3.4 \\
\hline Grants & 1.0 & 0.7 & 1.0 & 0.9 & 0.3 \\
\hline Total expenditure and net lending & 30.4 & 35.5 & 33.5 & 32.5 & 33.3 \\
\hline $\begin{array}{l}\text { Current expenditure } \\
\text { Of which: }\end{array}$ & 24.3 & 27.4 & 25.7 & 25.1 & 24.8 \\
\hline Wages and salaries & 11.8 & 12.5 & 14.2 & 13.9 & 13.1 \\
\hline Goods and services & 7.1 & 9.1 & 5.8 & 6.4 & 6.4 \\
\hline Interest payments & 1.2 & 1.1 & 1.1 & 0.9 & 1.0 \\
\hline Subsidies and transfers & 4.2 & 4.7 & 4.6 & 3.9 & 4.3 \\
\hline Capital expenditure & 5.8 & 8.0 & 8.2 & 7.7 & 8.2 \\
\hline Primary balance & -1.6 & -3.5 & -0.4 & 11.4 & 7.4 \\
\hline Overall balance (including grants) & -2.9 & -4.6 & -1.5 & 10.5 & 6.4 \\
\hline Overall balance (excluding grants) & -3.8 & -5.3 & -2.5 & 9.6 & 6.1 \\
\hline Financing & 2.9 & 4.6 & 1.5 & -10.5 & -6.4 \\
\hline Foreign (net) & 0.5 & 1.6 & 1.2 & -5.8 & -3.6 \\
\hline Domestic (net) & 2.3 & 2.9 & 0.3 & -4.7 & -6.9 \\
\hline Government debt & 20.1 & 17.9 & 15.9 & 17.4 & 18.8 \\
\hline Foreign & 17.6 & 14.6 & 13.4 & 14.7 & 16.7 \\
\hline Domestic & 2.6 & 3.2 & 2.5 & 2.7 & 2.1 \\
\hline \multicolumn{6}{|l|}{ Memorandum items: } \\
\hline Payment arrears & 0.8 & 2.0 & & & \\
\hline $\begin{array}{l}\text { GDP at current prices (in millions of } \\
\text { emalangeni) }\end{array}$ & 14,169 & 15,669 & 17,176 & 18,655 & 21,004 \\
\hline Wages and salaries (in percent of current ex & 48.6 & 45.7 & 55.3 & 55.3 & 52.7 \\
\hline
\end{tabular}

Sources: Ministry of Finance; and Fund staff projections.

${ }^{1}$ The fiscal year runs from April 1 to March 31. 
Table 13. Swaziland: Central Government Revenue and Grants, 2003/04-2007/08 ${ }^{1}$

\begin{tabular}{|c|c|c|c|c|c|}
\hline & $2003 / 04$ & $2004 / 05$ & 2005/06 & $2006 / 07$ & $2007 / 08$ \\
\hline & \multicolumn{5}{|c|}{ (In millions of emalangeni) } \\
\hline Tax revenue & $3,660.5$ & $4,627.8$ & $5,189.5$ & $7,682.8$ & $7,564.9$ \\
\hline Taxes on net income and profits & $1,105.4$ & $1,164.0$ & $1,267.4$ & $1,534.3$ & $1,644.4$ \\
\hline Companies & 322.4 & 324.0 & 472.5 & 560.9 & 522.1 \\
\hline Individuals & 698.7 & 742.0 & 761.7 & 892.4 & $1,058.4$ \\
\hline Nonresident dividends and interest & 84.3 & 98.0 & 33.3 & 81.0 & 63.9 \\
\hline Taxes on property & 9.0 & 12.0 & 13.3 & 10.3 & 18.1 \\
\hline Taxes on goods, services, and international tradı & $2,540.8$ & $3,445.8$ & $3,894.4$ & $6,102.2$ & $5,886.0$ \\
\hline Southern African Customs Union (SACU) recei & $1,878.1$ & $2,772.8$ & $3,101.1$ & $5,321.8$ & $4,989.9$ \\
\hline Sugar export levy & 12.1 & 22.0 & 21.1 & 33.1 & 32.1 \\
\hline Hotel and gaming taxes & 4.4 & 5.0 & 7.8 & 9.6 & 13.5 \\
\hline Licenses and other taxes & 98.5 & 97.0 & 29.4 & 27.2 & 30.3 \\
\hline Sales tax & 547.7 & 549.0 & 734.9 & 620.1 & 725.0 \\
\hline Road levy and oil tax & 0.0 & 0.0 & 0.0 & 90.3 & 95.2 \\
\hline Other taxes & 5.3 & 6.0 & 14.4 & 36.0 & 16.4 \\
\hline Nontax revenue & 104.9 & 98.0 & 137.3 & 172.0 & 713.5 \\
\hline Property income & 52.0 & 46.0 & 53.4 & 89.6 & 596.6 \\
\hline Fees, fines, and nonindustrial sales & 52.9 & 52.0 & 83.9 & 82.3 & 116.9 \\
\hline Total revenue & $3,765.4$ & $4,725.8$ & $5,326.8$ & $7,854.8$ & $8,278.4$ \\
\hline Grants & 137.7 & 116.0 & 172.2 & 165.6 & 62.8 \\
\hline \multirow[t]{2}{*}{ Total revenue and grants } & $3,903.1$ & $4,841.8$ & $5,499.1$ & $8,020.4$ & $8,341.1$ \\
\hline & \multicolumn{5}{|c|}{ (in percent of GDP) } \\
\hline Tax revenue & 25.8 & 29.5 & 30.2 & 41.2 & 36.0 \\
\hline Taxes on net income and profits & 7.8 & 7.4 & 7.4 & 8.2 & 7.8 \\
\hline Of which & & & & & \\
\hline Companies & 2.3 & 2.1 & 2.8 & 3.0 & 2.5 \\
\hline Individuals & 4.9 & 4.7 & 4.4 & 4.8 & 5.0 \\
\hline Taxes on property & 0.1 & 0.1 & 0.1 & 0.1 & 0.1 \\
\hline Taxes on goods, services, and international trad $\epsilon$ & 17.9 & 22.0 & 22.7 & 32.7 & 28.0 \\
\hline SACU receipts & 13.3 & 17.7 & 18.1 & 28.5 & 23.8 \\
\hline Sales tax & 3.9 & 3.5 & 4.3 & 3.3 & 3.5 \\
\hline Other taxes & 0.0 & 0.0 & 0.1 & 0.2 & 0.1 \\
\hline Nontax revenue & 0.7 & 0.6 & 0.8 & 0.9 & 3.4 \\
\hline Grants & 1.0 & 0.7 & 1.0 & 0.9 & 0.3 \\
\hline \multirow[t]{2}{*}{ Total revenue and grants } & 27.5 & 30.9 & 32.0 & 43.0 & 39.7 \\
\hline & \multicolumn{5}{|c|}{ (In percent of total revenue and grants) } \\
\hline Tax revenue & 93.8 & 95.6 & 94.4 & 95.8 & 90.7 \\
\hline Taxes on net income and profits & 28.3 & 24.0 & 23.0 & 19.1 & 19.7 \\
\hline \multicolumn{6}{|l|}{ Of which } \\
\hline Companies & 8.3 & 6.7 & 8.6 & 7.0 & 6.3 \\
\hline Individuals & 17.9 & 15.3 & 13.9 & 11.1 & 12.7 \\
\hline Taxes on property & 0.2 & 0.2 & 0.2 & 0.1 & 0.2 \\
\hline Taxes on goods, services, and international trad $\epsilon$ & 65.1 & 71.2 & 70.8 & 76.1 & 70.6 \\
\hline Of which: SACU receipts & 48.1 & 57.3 & 56.4 & 66.4 & 59.8 \\
\hline Other taxes & 0.1 & 0.1 & 0.3 & 0.4 & 0.2 \\
\hline Nontax revenue & 2.7 & 2.0 & 2.5 & 2.1 & 8.6 \\
\hline Grants & 3.5 & 2.4 & 3.1 & 2.1 & 0.8 \\
\hline \multicolumn{6}{|l|}{ Memorandum item: } \\
\hline GDP at current market prices (in millions of emal: & 14,169 & 15,669 & 17,176 & 18,655 & 21,004 \\
\hline
\end{tabular}

Source: Ministry of Finance.

${ }^{1}$ Fiscal year runs from April 1 to March 31. 
Table 14. Swaziland: Functional Classification of Central Government Expenditure and Net Lending, 2003/04-2007/08 ${ }^{1}$

\begin{tabular}{|c|c|c|c|c|c|}
\hline & $2003 / 04$ & $2004 / 05$ & $2005 / 06$ & $2006 / 07$ & $2007 / 08$ \\
\hline & \multicolumn{5}{|c|}{ (In millions of emalangeni) } \\
\hline & \multicolumn{5}{|c|}{ ( } \\
\hline Current expenditure & $3,437.2$ & $4,295.0$ & $4,416.3$ & $4,681.3$ & $5,217.3$ \\
\hline Wages and salaries & $1,668.9$ & $1,964.0$ & $2,443.0$ & $2,588.7$ & $2,750.2$ \\
\hline Of which: Health & 131.0 & 165.2 & 185.5 & 283.9 & 235.1 \\
\hline Education & 575.0 & 715.4 & 675.8 & $1,020.8$ & $1,157.0$ \\
\hline Other purchases of goods and services & $1,003.0$ & $1,421.0$ & 995.8 & $1,202.8$ & $1,343.0$ \\
\hline Of which: Health & 119.0 & 142.8 & 152.9 & 166.3 & 176.4 \\
\hline Education & 64.0 & 69.1 & 75.4 & 80.8 & 105.6 \\
\hline Interest payments & 173.8 & 168.0 & 194.4 & 163.4 & 211.3 \\
\hline Domestic & 37.0 & 49.0 & 31.6 & 35.3 & 84.9 \\
\hline Foreign & 136.8 & 119.0 & 162.9 & 128.1 & 126.4 \\
\hline Subsidies and other current transfers & 591.5 & 742.0 & 783.1 & 726.4 & 912.8 \\
\hline Of which: subsidies to NFPEs ${ }^{2}$ & 200.7 & 213.2 & 287.2 & 289.0 & 364.7 \\
\hline Capital expenditure & 817.8 & $1,259.0$ & $1,409.7$ & $1,436.6$ & $1,732.7$ \\
\hline Of which: Health & 60.0 & 82.6 & 47.8 & 48.5 & 69.8 \\
\hline Education & 13.0 & 27.9 & 18.9 & 42.6 & 82.2 \\
\hline Agriculture & 48.0 & 104.5 & 171.6 & 321.4 & 587.7 \\
\hline Transport and communications & 125.0 & 347.6 & 387.0 & 632.3 & 745.6 \\
\hline Other & 571.8 & 696.4 & 784.4 & 391.9 & 247.4 \\
\hline Net lending & 59.0 & 3.0 & -68.3 & -55.2 & 43.0 \\
\hline Gross lending & 68.3 & 10.0 & 0.0 & 0.0 & 58.0 \\
\hline Repayments & -9.3 & -7.0 & -68.3 & -55.2 & -15.0 \\
\hline Total expenditure and net lending & $4,314.0$ & $5,557.0$ & $5,757.7$ & $6,062.7$ & $6,992.9$ \\
\hline & \multicolumn{5}{|c|}{ (In percent of GDP) } \\
\hline Current expenditure & 24.3 & 27.4 & 25.7 & 25.1 & 24.8 \\
\hline Capital expenditure & 5.8 & 8.0 & 8.2 & 7.7 & 8.2 \\
\hline Net lending & 0.4 & 0.0 & -0.4 & -0.3 & 0.2 \\
\hline Total expenditure and net lending & 30.4 & 35.5 & 33.5 & 32.5 & 33.3 \\
\hline Current expenditure & 79.7 & 77.3 & 76.7 & 77.2 & 74.6 \\
\hline Wages and salaries & 38.7 & 35.3 & 42.4 & 42.7 & 39.3 \\
\hline Other purchases of goods and services & 23.2 & 25.6 & 17.3 & 19.8 & 19.2 \\
\hline Interest payments & 4.0 & 3.0 & 3.4 & 2.7 & 3.0 \\
\hline Subsidies and other current transfers & 13.7 & 13.4 & 13.6 & 12.0 & 13.1 \\
\hline Capital expenditure & 19.0 & 22.7 & 24.5 & 23.7 & 24.8 \\
\hline Net lending & 1.4 & 0.1 & -1.2 & -0.9 & 0.6 \\
\hline \multicolumn{6}{|l|}{ Memorandum item: } \\
\hline GDP at current market prices (in millions of emalangeni) & $14,169.3$ & $15,669.2$ & $17,176.0$ & $18,655.0$ & $21,003.8$ \\
\hline
\end{tabular}

Source: Ministry of Finance.

${ }^{1}$ Fiscal year runs from April 1 to March 31.

${ }^{2}$ NFPEs (nonfinancial public enterprises). 
Table 15. Swaziland: Economic Classification of Government Current Expenditure, 2003/04-2007/08 ${ }^{1}$

\begin{tabular}{|c|c|c|c|c|c|}
\hline & $2003 / 04$ & $2004 / 05$ & $2005 / 06$ & $2006 / 07$ & 200708 \\
\hline & \multicolumn{5}{|c|}{ (In millions of emalangeni) } \\
\hline General public service & $1,183.0$ & $1,448.4$ & 1379.9 & 1433.7 & 1486.8 \\
\hline General administration & 495.0 & 962.9 & 789.0 & 830.31 & 776.8 \\
\hline Public order and safety & 688.0 & 485.4 & 590.9 & 603.4 & 710.0 \\
\hline Defense & 255.0 & 282.8 & 410.0 & 391.7 & 450.7 \\
\hline Social services & $1,389.0$ & $1,689.0$ & $1,909.9$ & $2,143.4$ & 2535.0 \\
\hline Education & 911.0 & $1,130.3$ & $1,178.5$ & $1,308.9$ & 1605.4 \\
\hline Health & 291.0 & 348.0 & 492.8 & 521.67 & 571.6 \\
\hline Other & 156.0 & 174.7 & 182.3 & 259.1 & 289.8 \\
\hline Water and sewerage & 31.0 & 36.0 & 56.3 & 53.7 & 68.1 \\
\hline Economic services & 476.2 & 706.7 & 522.1 & 549.1 & 533.5 \\
\hline Agriculture & 147.0 & 203.0 & 159.5 & 153.4 & 207.9 \\
\hline Manufacturing, mining, and construction & 58.0 & 69.0 & 13.3 & 13.1 & 15.4 \\
\hline Transport and communications & 187.0 & 231.0 & 205.4 & 163.3 & 223.1 \\
\hline Other & 84.2 & 203.7 & 143.9 & 219.3 & 87.2 \\
\hline Interest payments & 134.0 & 168.0 & 194.4 & 163.4 & 211.3 \\
\hline \multirow[t]{2}{*}{ Total } & $3,437.2$ & $4,294.9$ & $4,416.3$ & $4,681.3$ & $5,217.3$ \\
\hline & \multicolumn{5}{|c|}{ (In percent of GDP) } \\
\hline General public service & 8.3 & 9.2 & 8.0 & 7.7 & 7.1 \\
\hline General administration & 3.5 & 6.1 & 4.6 & 4.5 & 3.7 \\
\hline Public safety and defense & 4.9 & 3.1 & 3.4 & 3.2 & 3.4 \\
\hline Defense & 1.8 & 1.8 & 2.4 & 2.1 & 2.1 \\
\hline Social services & 9.8 & 10.8 & & & \\
\hline Education & 6.4 & 7.2 & 6.9 & 7.0 & 7.6 \\
\hline Health & 2.1 & 2.2 & 2.9 & 2.8 & 2.7 \\
\hline Other & 1.1 & 1.1 & 1.1 & 1.4 & 1.4 \\
\hline Economic services & 3.4 & 4.5 & 3.0 & 2.9 & 2.5 \\
\hline Interest payments & 0.9 & 1.1 & 1.1 & 0.9 & 1.0 \\
\hline General public service & 34.4 & 33.7 & 31.2 & 30.6 & 28.5 \\
\hline General administration & 14.4 & 22.4 & 17.9 & 17.7 & 14.9 \\
\hline Public safety and defense & 20.0 & 11.3 & 13.4 & 12.9 & 13.6 \\
\hline Defense & 7.4 & 6.6 & 9.3 & 8.4 & 8.6 \\
\hline Social services & 40.4 & 39.3 & 43.2 & 45.8 & 48.6 \\
\hline Education & 26.5 & 26.3 & 26.7 & 28.0 & 30.8 \\
\hline Health & 8.5 & 8.1 & 11.2 & 11.1 & 11.0 \\
\hline Other & 4.5 & 4.1 & 4.1 & 5.5 & 5.6 \\
\hline Economic services & 13.9 & 16.5 & 11.8 & 11.7 & 10.2 \\
\hline Interest payments & 3.9 & 3.9 & 4.4 & 3.5 & 4.1 \\
\hline \multicolumn{6}{|l|}{ Memorandum item: } \\
\hline GDP at current market prices (in millions of emala। & $14,169.3$ & $15,669.2$ & $17,176.0$ & $18,655.0$ & $21,003.8$ \\
\hline
\end{tabular}

Source: Ministry of Finance.

' Fiscal year runs from April 1 to March 31. 
Table 16. Swaziland: Capital Expenditure by Sector, 2003/04-2007/08 ${ }^{1}$ (In millions of emalangeni)

\begin{tabular}{|c|c|c|c|c|c|}
\hline & $2003 / 04$ & $2004 / 05$ & $2005 / 06$ & $2006 / 07$ & $2007 / 08$ \\
\hline General public services & 67.0 & 408.1 & 492.5 & 484.4 & 520.3 \\
\hline General administration & 28.0 & 365.6 & 398.2 & 415.4 & 406.2 \\
\hline Public safety and defense & 39.0 & 42.5 & 94.3 & 69.0 & 114.0 \\
\hline Social services & 282.0 & 360.0 & 291.4 & 245.0 & 369.7 \\
\hline Education & 13.0 & 28.0 & 18.9 & 32.9 & 78.6 \\
\hline Health & 60.0 & 83.0 & 47.8 & 48.5 & 52.7 \\
\hline Housing & 193.0 & 247.0 & 179.3 & 123.8 & 132.1 \\
\hline Recreation and culture & 7.0 & 1.1 & 13.2 & 18.1 & 75.7 \\
\hline Other & 9.0 & 0.9 & 32.2 & 21.7 & 30.6 \\
\hline Economic services & 468.8 & 490.9 & 625.7 & 707.3 & 842.7 \\
\hline Agriculture & 48.0 & 105.0 & 171.6 & 122.7 & 226.4 \\
\hline Industry and mining & 4.0 & 23.0 & 6.0 & 27.1 & 27.0 \\
\hline Water and sewage & 13.0 & 9.0 & 56.5 & 162.4 & 114.6 \\
\hline Transport and communications & 125.0 & 348.0 & 387.0 & 381.1 & 451.5 \\
\hline Other & 278.8 & 5.9 & 4.6 & 14.1 & 23.2 \\
\hline Total capital expenditure & 817.8 & $1,259.0$ & 1409.6 & 1436.6 & 1732.7 \\
\hline
\end{tabular}

Source: Ministry of Finance.

${ }^{1}$ Fiscal year runs from April 1 to March 31. 
Table 17. Swaziland: Government Transfer Payments, 2003/04-2007/08 ${ }^{1}$

(In millions of emalangeni, unless otherwise indicated)

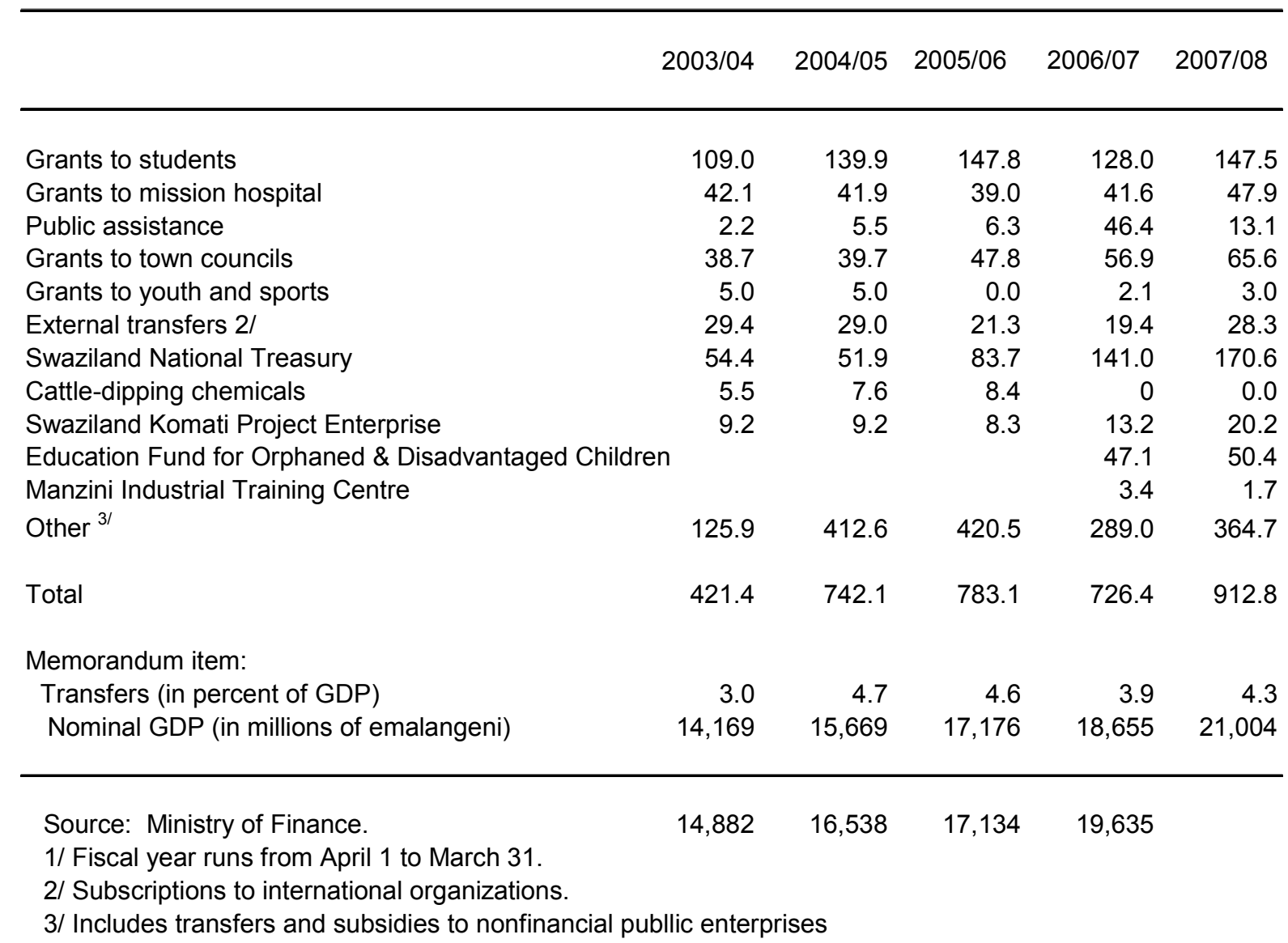


Table 18. Swaziland: Flow of Funds From the Government to Public Enterprises 2003/04-2007/08 (In millions of emalangeni, unless otherwise indicated)

\begin{tabular}{|c|c|c|c|c|c|}
\hline & $2003 / 04$ & $2004 / 05$ & $2005 / 06$ & $2006 / 07$ & 2007/08 \\
\hline Total subsidies to public enterprises & 200.7 & 213.2 & 287.2 & 289.0 & 364.7 \\
\hline Operating/Transport subsidy & 169.5 & 172.5 & 187.4 & & 51.7 \\
\hline Capital subsidy (flow) & 31.2 & 40.7 & 99.8 & & 313.0 \\
\hline Total subsidies to public enterprises & 200.7 & 213.2 & 287.2 & 289.0 & 364.7 \\
\hline Swaziland Development \& Savings Bank & 0.0 & 0.0 & 0.0 & 0.0 & 0.0 \\
\hline Subsidies to nonfinancial public enterprises & 200.7 & 213.2 & 287.2 & 289.0 & 364.7 \\
\hline Joint Venture Capital Fund & 0.0 & 0.0 & 0.0 & 0.0 & 0.0 \\
\hline Swaziland Water Services Corporation & 0.0 & 0.0 & 36.5 & 13.2 & 38.5 \\
\hline Swaziland Investment Promotion Authority & 3.9 & 4.7 & 7.8 & 25.2 & 5.6 \\
\hline Swaziland Television Authority & 10.1 & 10.1 & 32.6 & 29.3 & 36.0 \\
\hline Sebenta National Institute & 2.7 & 2.7 & 2.9 & 2.9 & 3.0 \\
\hline Swaziland National Trust Commission & 7.3 & 8.3 & 25.3 & 11.9 & 12.9 \\
\hline University of Swaziland & 109.3 & 109.3 & 109.3 & 130.8 & 142.2 \\
\hline Motor Vehicle Accident Fund & 0.0 & 0.0 & 0.0 & 0.0 & 9.0 \\
\hline Swaziland Water \& Agricultural Development Enterprise (wa: & 38.6 & 38.6 & 28.7 & 22.0 & 45.6 \\
\hline Commission for Mediation etc. & 2.6 & 5.4 & 7.2 & 5.8 & 9.2 \\
\hline National Emergency Response Committee & 20.0 & 20.0 & 20.0 & 30.3 & 45.0 \\
\hline Swailand Environment Authority & 0.0 & 0.0 & 0.0 & 1.5 & 3.0 \\
\hline Swaziland Tourism Authority & 0.0 & 0.0 & 3.8 & 7.8 & 6.8 \\
\hline Swaziland Cotton Board (Revolving Fund) & 0.0 & 0.0 & 0.0 & 1.0 & 1.0 \\
\hline Swaziland Standards Authority & 0.0 & 0.0 & 0.0 & 1.0 & 2.9 \\
\hline Small Enterprises Development Company & & & 3.7 & 3.7 & 4.0 \\
\hline Other & 6.2 & 14.1 & 16.9 & 2.7 & \\
\hline \multicolumn{6}{|l|}{ Memorandum item: } \\
\hline Total Subsidies (in percent of GDP) & 1.4 & 1.4 & 1.7 & 1.5 & 1.7 \\
\hline Nominal GDP (in millions of emalangeni) & 14,169 & 15,669 & 17,176 & 18,655 & 21,004 \\
\hline
\end{tabular}

Source: Ministry of Finance.

1/ Fiscal year runs from April 1 to March 31. 
Table 19. Swaziland: Outstanding Domestic Government Debt by Type of Instrument, 2003-08 (In millions of emalangeni; end of period)

\begin{tabular}{|c|c|c|c|c|c|c|}
\hline & 2003 & 2004 & 2005 & 2006 & 2007 & Mar-08 \\
\hline Government bonds and stocks & 260.0 & 180.0 & 99.0 & 50.0 & 50.0 & 50.0 \\
\hline Central Bank of Swaziland & 0.0 & 0.0 & 19.0 & 0.0 & 0.0 & 0.0 \\
\hline Banks & 176.7 & 146.3 & 59.3 & 39.0 & 39.0 & 39.0 \\
\hline Other financial institutions & 53.9 & 14.5 & 6.5 & 5.0 & 5.0 & 5.0 \\
\hline Other & 29.4 & 19.2 & 14.2 & 6.0 & 6.0 & 6.0 \\
\hline Treasury bills $1 /$ & 217.7 & 374.0 & 427.3 & 422.0 & 365.1 & 390.0 \\
\hline Central Bank of Swaziland & 40.0 & 73.0 & 50.0 & 55.7 & 22.7 & 0.1 \\
\hline Banks & 160.0 & 280.0 & 234.4 & 337.2 & 318.3 & 374.8 \\
\hline Other & 17.7 & 21.0 & 143.0 & 29.1 & 24.1 & 15.1 \\
\hline $\begin{array}{l}\text { Total domestic government debt } \\
\text { By original maturity }\end{array}$ & 477.7 & 554.0 & 507.3 & 472.0 & 415.1 & 440.0 \\
\hline Less than one year & 217.7 & 374.0 & 427.3 & 422.0 & 365.1 & 390.0 \\
\hline From one to five years & 210.0 & 130.0 & 0.0 & 0.0 & 0.0 & 0.0 \\
\hline From five to ten years & 50.0 & 50.0 & 80.0 & 50.0 & 50.0 & 50.0 \\
\hline Over ten years & 0.0 & 0.0 & 0.0 & 0.0 & 0.0 & 0.0 \\
\hline
\end{tabular}

Source: Central Bank of Swaziland.

$1 /$ The maturity of treasury bills is three months. 
Table 20. Swaziland: Monetary Survey, 2003-08 ${ }^{1}$

\begin{tabular}{|c|c|c|c|c|c|c|}
\hline & 2003 & 2004 & 2005 & 2006 & 2007 & $\begin{array}{c}2008 \\
\text { June }\end{array}$ \\
\hline & \multicolumn{5}{|c|}{ (In millions of Emalangeni) } & \\
\hline \multicolumn{7}{|l|}{ Monetary authorities } \\
\hline Net foreign assets & $1,404.7$ & $1,450.2$ & $1,518.4$ & $2,584.6$ & $5,059.6$ & $5,817.8$ \\
\hline Central Bank of Swaziland (CBS) & $1,378.2$ & $1,243.3$ & $1,518.4$ & $2,549.2$ & $3,780.0$ & $5,817.8$ \\
\hline Of which: Capital Investment Fund (CIF), managed by CBS. & 712.9 & 666.7 & 0.0 & 0.0 & 0.0 & 0.0 \\
\hline Government 2/ & 26.5 & 206.9 & 0.0 & 35.4 & $1,279.6$ & 0.0 \\
\hline Net domestic assets & -974.8 & -973.2 & $-1,028.5$ & $-2,018.5$ & $-4,353.9$ & $-5,047.0$ \\
\hline Central government (net) & $-1,030.8$ & -933.2 & $-1,082.5$ & $-1,960.0$ & $-4,048.6$ & $-4,487.9$ \\
\hline CBS claims on government & 82.6 & 251.8 & 100.6 & 55.1 & 14.7 & 10.9 \\
\hline Government deposits & $-1,113.4$ & $-1,185.0$ & $-1,183.0$ & $-2,015.1$ & $-4,063.4$ & $-4,498.8$ \\
\hline Domestic & -374.0 & -311.3 & $-1,183.0$ & $-1,976.1$ & $-2,780.2$ & $-4,494.9$ \\
\hline Foreign 2/ & -739.4 & -873.6 & 0.0 & -38.9 & $-1,283.2$ & -3.9 \\
\hline Private sector & 12.0 & 10.0 & 8.9 & 20.5 & 7.5 & 9.4 \\
\hline Commercial banks (net) & 0.0 & 0.0 & 2.3 & 21.9 & 1.9 & 1.9 \\
\hline Other items (net) & 44.0 & -50.0 & 42.7 & -100.8 & -314.7 & -570.5 \\
\hline Reserve money & 430.3 & 477.1 & 489.9 & 566.1 & 705.7 & 770.7 \\
\hline \multicolumn{7}{|l|}{ Commercial banks } \\
\hline Net foreign assets & 469.4 & 490.4 & 374.5 & 761.9 & 697.5 & $1,145.4$ \\
\hline Reserves & 194.0 & 211.0 & 210.5 & 353.6 & 499.0 & 525.0 \\
\hline Domestic credit & $2,614.1$ & $3,344.2$ & $3,832.3$ & $4,581.2$ & $5,385.3$ & $5,506.8$ \\
\hline Central government (net) & 286.4 & 331.0 & 301.7 & 305.5 & 169.1 & 80.1 \\
\hline Claims on Government & 286.7 & 332.5 & 315.0 & 369.4 & 343.7 & 378.7 \\
\hline Government deposits & 0.3 & 1.5 & 13.3 & 63.8 & 174.6 & 298.6 \\
\hline Private sector & $2,327.7$ & $3,013.2$ & $3,530.6$ & $4,275.7$ & $5,216.3$ & $5,426.7$ \\
\hline Other items (net) & -613.0 & $-1,100.0$ & $-1,196.1$ & $-1,588.6$ & $-1,559.3$ & $-1,696.9$ \\
\hline Private sector deposits & $2,663.7$ & $2,945.9$ & $3,221.2$ & $4,088.2$ & $5,022.5$ & $5,480.3$ \\
\hline \multicolumn{7}{|l|}{ Monetary survey } \\
\hline Net foreign assets & $1,874.1$ & $1,940.6$ & $1,892.9$ & $3,346.5$ & $5,757.1$ & $6,963.2$ \\
\hline Domestic credit & $1,595.3$ & $2,421.0$ & $2,758.7$ & $2,641.7$ & $1,344.2$ & $1,028.3$ \\
\hline Central government (net) & -744.4 & -602.2 & -780.8 & $-1,654.4$ & $-3,879.6$ & $-4,407.8$ \\
\hline Private sector & $2,339.7$ & $3,023.2$ & $3,539.5$ & $4,296.2$ & $5,223.8$ & $5,436.1$ \\
\hline Other items (net) & -500.4 & $-1,083.6$ & $-1,180.5$ & $-1,646.3$ & $-1,828.5$ & $-2,235.2$ \\
\hline Broad money & $2,969.0$ & $3,278.0$ & $3,471.0$ & $4,342.0$ & $5,272.8$ & $5,756.4$ \\
\hline Currency in circulation $3 /$ & 213.5 & 235.8 & 242.1 & 250.5 & 248.6 & 274.6 \\
\hline \multirow[t]{2}{*}{ Deposits } & $2,755.5$ & $3,042.2$ & $3,228.9$ & $4,091.4$ & $5,024.2$ & $5,481.8$ \\
\hline & \multicolumn{6}{|c|}{ (Annual change in percent of beginning-of-period broad money) } \\
\hline Broad money & 14.1 & 10.4 & 5.9 & 25.1 & 21.4 & 14.1 \\
\hline Net foreign assets & -27.5 & 2.2 & -1.5 & 41.9 & 55.5 & 37.8 \\
\hline Domestic credit & 34.5 & 27.8 & 10.3 & -3.4 & -29.9 & 26.7 \\
\hline Central government (net) & 13.1 & 4.8 & -5.4 & -25.2 & -51.2 & 14.7 \\
\hline Private sector & 21.4 & 23.0 & 15.7 & 21.8 & 21.4 & 12.0 \\
\hline Other items (net) & 7.1 & -19.6 & -3.0 & -13.4 & -4.2 & -50.4 \\
\hline \multicolumn{7}{|l|}{ Memorandum items: } \\
\hline Currency/broad money (percent) & 7.2 & 7.2 & 7.0 & 5.8 & 4.7 & 4.8 \\
\hline Reserve money/deposits (percent) & 15.6 & 15.7 & 15.2 & 13.8 & 14.0 & 14.1 \\
\hline Money multiplier (broad money/reserve money) & 6.9 & 6.9 & 7.1 & 7.7 & 7.5 & 7.5 \\
\hline Velocity (GDP/period average broad money) & 4.9 & 4.9 & 4.5 & 4.4 & 4.2 & 4.1 \\
\hline
\end{tabular}

Sources: Central Bank of Swaziland (CBS); and Fund staff estimates.

1/ End-of-year data.

2/ Beginning in end-2006, includes government holdings abroad.

3/ Excludes rand in circulation. 
Table 21. Swaziland: Assets and Liabilities of the Central Bank of Swaziland, 2003-07 (In millions of emalangeni, end of period)

\begin{tabular}{lrrrrr}
\hline & 2003 & 2004 & 2005 & 2006 & 2007 \\
\hline Foreign assets & & & & & \\
CBS managed 1/ & 1,758 & 1,474 & 1,536 & 2,697 & 5,166 \\
Government & 1,732 & 1,267 & 1,536 & 2,662 & 3,886 \\
Claims on government & 27 & 207 & 0 & 35 & 1,280 \\
Claims on private sector & 83 & 252 & 101 & 55 & 15 \\
Claims on commercial banks & 12 & 10 & 9 & 20 & 8 \\
& 0 & 0 & 2 & 22 & 2 \\
Assets = liabilities & & & & & \\
& 1,853 & 1,736 & 1,648 & 2,795 & 5,190 \\
Foreign liabilities & & & & & 106 \\
Government deposits 2/ & 355 & 25 & 18 & 113 & 106 \\
$\quad$ Of which: holdings abroad & 1,087 & 978 & 1,183 & 2,015 & 4,063 \\
Private sector deposits & 713 & 667 & 0 & 39 & 1,283 \\
Commercial banks & 92 & 96 & 8 & 3 & 2 \\
Reserve money & 0 & 0 & 0 & 0 & 1 \\
$\quad$ Currency in circulation 3/ & 430 & 477 & 490 & 566 & 706 \\
Commercial bank deposits & 286 & 302 & 341 & 379 & 408 \\
& 145 & 175 & 149 & 188 & 298 \\
Other items (net) 4/ & -111 & 159 & -50 & 98 & 313 \\
& & & & & \\
\hline
\end{tabular}

Source: Central Bank of Swaziland (CBS).

1/ Includes Capital Investment Fund, until 2005

$2 /$ Includes counterpart of government foreign assets.

3/ Excludes rand in circulation.

4/ Includes balances held with other banks in Swaziland, bills payable, unclassified assets, and unclassified liabilities. 
Table 22. Swaziland: Assets and Liabilities of Commercial Banks, 2003-0 ${ }^{1}$ (In millions of emalangeni, end of period)

\begin{tabular}{|c|c|c|c|c|c|}
\hline & 2003 & 2004 & 2005 & 2006 & 2007 \\
\hline Foreign assets & 521 & 531 & 443 & 419 & 766 \\
\hline Claims on government & 287 & 332 & 315 & 309 & 344 \\
\hline Claims on private sector & 2,328 & 3,013 & 3,531 & 3,635 & 5,216 \\
\hline Reserves & 236 & 256 & 211 & 211 & 499 \\
\hline Balances with CBS & 121 & 146 & 111 & 111 & 284 \\
\hline Cash in tills $2 /$ & 72 & 66 & 99 & 99 & 159 \\
\hline CBS bills & 0 & 0 & 0 & 0 & 56 \\
\hline Other items (net) $3 /$ & -168 & -103 & 587 & 1,109 & 4 \\
\hline Assets $=$ liabilities & 3,204 & 4,030 & 5,087 & 5,683 & 6,828 \\
\hline Foreign liabilities & 52 & 41 & 69 & 124 & 68 \\
\hline Government deposits & 0 & 2 & 13 & 64 & 175 \\
\hline Private sector deposits & 2,664 & 2,946 & 3,898 & 4,088 & 5,023 \\
\hline Demand & 834 & 844 & 1,046 & 1,106 & 1,417 \\
\hline Time & 1,353 & 1,517 & 2,175 & 2,982 & 3,605 \\
\hline Savings & 476 & 585 & 677 & 0 & 0 \\
\hline Balances due to CBS & 0 & 34 & 0 & 20 & 0 \\
\hline Capital accounts & 488 & 1,007 & 1,106 & 1,387 & 1,563 \\
\hline
\end{tabular}

Source: Central Bank of Swaziland (CBS).

1/ Includes the Swaziland Development and Savings Bank.

2/ Excludes rand in circulation.

3/ Includes balances held with other banks in Swaziland, bills payable, unclassified assets, and unclassified liabilities. 
Table 23. Swaziland: Commercial Banks' Deposits by Sector, 2003-0 ${ }^{1}$ (In millions of emalangeni, end of period)

\begin{tabular}{lrrrrr}
\hline & 2003 & 2004 & 2005 & 2006 & 2007 \\
& & & & & \\
\hline Demand deposits & 834 & 845 & 1055 & 1110 & 1430 \\
Central government & 3 & 1 & 6 & 1 & 9 \\
Other public bodies 2/ & 49 & 23 & 63 & 37 & 57 \\
Personal & 264 & 201 & 235 & 172 & 265 \\
Business & 517 & 620 & 751 & 900 & 1099 \\
& & & & & \\
Savings deposits & 477 & 586 & 679 & 699 & 1038 \\
Central government & 0 & 0 & 0 & 0 & 1 \\
Other public bodies 2l & 2 & 0 & 0 & 0 & 29 \\
Personal & 436 & 492 & 646 & 447 & 811 \\
Business & 38 & 94 & 33 & 252 & 197 \\
& & & & & \\
Time deposits & 1,353 & 1,517 & 1,498 & 1,783 & 2,740 \\
Central government & 0 & 0 & 7 & 9 & 165 \\
Other public bodies 2l & 291 & 106 & 351 & 237 & 281 \\
Personal & 264 & 230 & 250 & 193 & 478 \\
Business & 798 & 1182 & 890 & 1345 & 1815 \\
Total deposits & & & & & \\
Central government & 2,663 & 2,948 & 3,233 & 3,593 & 5,207 \\
Other public bodies 2l & 0 & 2 & 13 & 10 & 175 \\
Personal & 342 & 129 & 415 & 274 & 367 \\
Business & 964 & 922 & 1,131 & 813 & 1,554 \\
& 1,353 & 1,896 & 1,674 & 2,496 & 3,112 \\
\hline
\end{tabular}

Source: Central Bank of Swaziland (CBS).

1/ Excluding bank checks outstanding.

2/ Comprises local government, city councils, and statutory corporations. 
Table 24. Swaziland: Commercial Banks' Liquidity Position, 2002-07

(In millions of emalangeni, end of period)

\begin{tabular}{|c|c|c|c|c|c|}
\hline & 2003 & 2004 & 2005 & 2006 & 2007 \\
\hline Total liquid assets $1 /$ & 508 & 561 & 549 & 741 & 857 \\
\hline Of which: balance with CBS & 121 & 146 & 111 & 225 & 282 \\
\hline Required liquid assets & 371 & 415 & 446 & 529 & 609 \\
\hline Domestic liquidity surplus & 137 & 146 & 102 & 212 & 248 \\
\hline Net due from foreign banks & 397 & 394 & 291 & 715 & 663 \\
\hline Total liquidity surplus & 533 & 540 & 393 & 927 & 911 \\
\hline \multicolumn{6}{|l|}{ Memorandum items: } \\
\hline Required liquidity to deposits & 13 & 13 & 13 & 13 & 13 \\
\hline Actual liquidity to deposits & 17 & 17 & 15 & 17.7 & 17.8 \\
\hline
\end{tabular}

Source: Central Bank of Swaziland (CBS).

$1 /$ Comprises cash in tills, treasury bills and eligible stock issued by the Swazi government, balances with the CBS and other banks, and other approved liquid assets. Also including rand notes and coins held by banks. 
Table 25. Swaziland: Commercial Bank Loans and Advances by Category of Borrower, 2003-07 (In millions of emalangeni, end of period)

\begin{tabular}{lrrrrr}
\hline & 2003 & 2004 & 2005 & 2006 & 2007 \\
\hline Industry & & & & & \\
$\quad$ Agriculture and forestry & 1,578 & 1,877 & 2,465 & 2,367 & 2,967 \\
$\quad$ Mining and quarrying & 365 & 403 & 598.4 & 273 & 399 \\
Manufacturing & 7 & 0 & 1 & 0 & 1 \\
Construction & 486 & 428 & 393.2 & 291 & 317 \\
Distribution and tourism & 118 & 136 & 201.3 & 252 & 140 \\
Transport and communications & 178 & 307 & 379.6 & 457 & 628 \\
Social and personal services & 115 & 196 & 205.2 & 177 & 247 \\
Other & 138 & 137 & 140.1 & 140 & 144 \\
& 171 & 269 & 546.7 & 777 & 1092 \\
Personal loans 1/ & & & & & \\
Statutory bodies & 530 & 874 & 1,030 & 1,294 & 1583 \\
Other 2/ & 38 & 70 & 70.1 & 50 & 71 \\
& 91 & 10 & 17 & 23 & 25 \\
Total & & & & & \\
& 2,237 & 2,830 & 3,582 & 3,733 & 4,646 \\
\hline
\end{tabular}

Source: Central Bank of Swaziland (CBS).

1/ Includes small amounts lent to nonresidents.

2/ Local authorities and private financial institutions. 
Table 26. Interest Rates in Swaziland and South Africa, 2003-08

(In percent)

\begin{tabular}{|c|c|c|c|c|c|c|c|}
\hline & 2003 & 2004 & 2005 & 2006 & $\begin{array}{r}2007 \\
\text { Dec } \\
\end{array}$ & $\begin{array}{r}2008 \\
\text { March } \\
\end{array}$ & $\begin{array}{l}2008 \\
\text { June }\end{array}$ \\
\hline \multicolumn{8}{|l|}{ Discount rates } \\
\hline Central Bank of Swaziland & 8.0 & 7.5 & 7.00 & 9.00 & 11.00 & 11.00 & 11.50 \\
\hline South African Reserve Bank & 8.0 & 7.5 & 7.00 & 9.00 & 11.00 & 11.00 & 12.00 \\
\hline \multicolumn{8}{|l|}{ Treasury bills } \\
\hline Swaziland & 7.9 & 7.6 & 6.90 & 8.50 & 9.96 & 9.88 & 10.30 \\
\hline South Africa & 7.5 & 7.5 & 9.80 & 8.50 & 10.00 & 10.04 & 10.51 \\
\hline \multicolumn{8}{|l|}{ Prime lending rate } \\
\hline Swaziland & 11.5 & 11.0 & 10.50 & 12.50 & 14.50 & 14.50 & 15.00 \\
\hline South Africa & 11.5 & 11.0 & 10.50 & 12.50 & 14.50 & 14.50 & 15.50 \\
\hline \multicolumn{8}{|l|}{ Bank time deposits } \\
\hline Swaziland-3l days & 4.4 & 3.9 & 3.40 & 5.41 & 7.30 & 7.30 & 7.66 \\
\hline South Africa-3l days & 7.4 & 7.2 & 6.80 & 8.90 & 10.94 & 11.05 & 11.46 \\
\hline Swaziland-12 months & 4.2 & 4.1 & 3.50 & 8.50 & 10.00 & 10.00 & 10.68 \\
\hline South Africa-12 months & 7.9 & 7.3 & 7.30 & 9.60 & 11.81 & 11.97 & 12.83 \\
\hline \multicolumn{8}{|l|}{ Bank savings deposits, } \\
\hline Swaziland 1/ & $1.0-6.5$ & $0.0-6.5$ & $0.0-6.5$ & $0.0-6.9$ & $0.0-9.91$ & & \\
\hline
\end{tabular}

Source: Central Bank of Swaziland (CBS).

1/ Simple average of end-of-period minimum and maximum rates across banks: rates on large-scale interbank deposits, as well as other money rates, often diverge widely from the deposit rates offered to the general public in Swaziland. 
Table 27. Swaziland: Balance of Payments, 2003-0 1

(Millions of U.S. dollars, unless otherwise specified)

\begin{tabular}{|c|c|c|c|c|c|}
\hline & 2003 & 2004 & 2005 & 2006 & 2007 \\
\hline Current account balance & 124.2 & 51.7 & -102.6 & -196.7 & -41.2 \\
\hline Trade balance & 103.8 & 91.0 & -258.1 & -252.1 & -246.5 \\
\hline Exports, f.o.b. & $1,387.1$ & $1,808.9$ & $1,636.5$ & $1,663.9$ & 1766.8 \\
\hline Imports, f.o.b. & $-1,283.2$ & $-1,717.9$ & $-1,894.6$ & $-1,916.1$ & -2013.3 \\
\hline Services (net) & -66.7 & -152.6 & -120.4 & -90.1 & -52.1 \\
\hline Exports of services & 193.1 & 250.0 & 282.4 & 283.5 & 454.1 \\
\hline Imports of services & -259.9 & -402.6 & -402.8 & -373.6 & -506.2 \\
\hline Goods and services balance & 37.1 & -61.6 & -378.5 & -342.3 & -298.6 \\
\hline Income (net) & 40.8 & 7.4 & 178.3 & 14.0 & 63.7 \\
\hline Income (credits) & 143.5 & 132.5 & 271.3 & 241.8 & 280.5 \\
\hline Income (debits) & -102.8 & -125.1 & -93.0 & -227.8 & -216.8 \\
\hline Of which: interest & -18.1 & -21.2 & -20.1 & -21.9 & -24.5 \\
\hline Transfers (net) & 46.3 & 106.0 & 97.5 & 131.6 & 193.7 \\
\hline Official sector (mainly SACU receipts) ${ }^{2}$ & 333.3 & 371.4 & 339.6 & 366.5 & 403.0 \\
\hline Private sector & -287.0 & -265.4 & -242.1 & -234.9 & -209.2 \\
\hline Capital and financial account balance & 114.7 & -206.6 & -46.7 & 158.6 & 404.0 \\
\hline Capital account balance & 0.0 & -0.6 & -3.5 & 24.8 & -30.1 \\
\hline Financial account balance (excluding reserve assets) & 114.7 & -206.0 & -43.2 & 133.8 & 434.1 \\
\hline Direct investment & 70.7 & 66.4 & -23.8 & 121.7 & 14.3 \\
\hline Portfolio investment & -0.4 & -11.3 & 4.5 & -4.0 & 5.2 \\
\hline Other investment & 44.4 & -261.2 & -23.9 & 16.0 & 414.5 \\
\hline Errors and omissions & -161.6 & 141.4 & 148.2 & 162.7 & -4.5 \\
\hline Overall balance & 77.3 & -13.5 & -1.1 & 124.6 & 358.3 \\
\hline \multicolumn{6}{|l|}{ Memorandum items: } \\
\hline Current account/GDP (percent) & 6.8 & 2.2 & -4.1 & -7.4 & -1.4 \\
\hline Goods and services balance/GDP (percent) & 2.0 & -2.6 & -15.0 & -12.8 & -10.3 \\
\hline Gross official reserves (end of period) & 264.8 & 261.8 & 244.4 & 367.4 & 747.2 \\
\hline In months of imports of goods and services & 2.1 & 1.5 & 1.3 & 1.9 & 3.6 \\
\hline Lilangeni per U.S. dollar (end of period) & 6.64 & 5.63 & 6.33 & 6.97 & 6.8 \\
\hline Lilangeni per U.S. dollar (period average) & 7.56 & 6.45 & 6.36 & 6.77 & 7.1 \\
\hline Exports fob, volume growth & 0.6 & 34.4 & -15.5 & -2.6 & -3.7 \\
\hline Imports fob, volume growth & -15.4 & -1.9 & -2.0 & -2.4 & 4.0 \\
\hline
\end{tabular}

Sources: Central Bank of Swaziland; and IMF staff projections.

${ }^{1}$ Without corrective policy measures.

${ }^{2}$ SACU: Southern African Customs Union. SACU transfers in the current account does not reflect the true level of SACU revenue because of the particular treatment of those transfers in the accounts where the authorities make an estimate based on the level of imports and adjust in 'other investment' to reflect the total SACU revenues. 
Table 28. Swaziland: Balance of Payments, 2003-0 ${ }^{1}$

(Millions of emalageni, unless otherwise specified)

\begin{tabular}{|c|c|c|c|c|c|}
\hline & 2003 & 2004 & 2005 & 2006 & 2007 \\
\hline Current account balance & 939.7 & 333.7 & -652.8 & $-1,331.3$ & -290.2 \\
\hline Trade balance & 785.4 & 587.0 & $-1,642.2$ & $-1,706.3$ & $-1,737.7$ \\
\hline Exports, f.o.b. & $10,492.8$ & $11,667.3$ & $10,412.2$ & $11,260.2$ & $12,456.1$ \\
\hline Imports, f.o.b. & $-9,707.4$ & $-11,080.3$ & $-12,054.3$ & $-12,966.5$ & $-14,193.8$ \\
\hline Services (net) & -504.6 & -984.3 & -766.2 & -610.0 & -367.3 \\
\hline Exports of services & $1,461.1$ & $1,612.5$ & $1,796.8$ & $1,918.3$ & $3,201.4$ \\
\hline Imports of services & $-1,965.7$ & $-2,596.8$ & $-2,563.0$ & $-2,528.3$ & $-3,568.7$ \\
\hline Goods and services balance & 280.8 & -397.3 & $-2,408.4$ & $-2,316.3$ & $-2,105.0$ \\
\hline Income (net) & 308.3 & 47.5 & $1,134.3$ & 94.7 & 449.0 \\
\hline Income (credits) & $1,085.7$ & 854.5 & $1,725.9$ & $1,636.5$ & $1,977.3$ \\
\hline Income (debits) & -777.4 & -807.0 & -591.6 & $-1,541.8$ & $-1,528.2$ \\
\hline Of which: interest & -137.1 & -136.6 & -128.0 & -148.4 & -172.6 \\
\hline Transfers (net) & 350.6 & 683.5 & 620.1 & 890.3 & $1,365.7$ \\
\hline Official sector (mainly SACU receipts) ${ }^{2}$ & $2,521.4$ & $2,395.6$ & $2,160.7$ & $2,480.2$ & $2,840.8$ \\
\hline Private sector & $-2,170.8$ & $-1,712.1$ & $-1,540.6$ & $-1,589.9$ & $-1,475.1$ \\
\hline Capital and financial account balance & 867.3 & $-1,332.5$ & -297.2 & $1,073.3$ & $2,848.2$ \\
\hline Capital account balance & 0.0 & -3.7 & -22.2 & 167.8 & -212.2 \\
\hline Financial account balance (excluding reserve assets) & 867.3 & $-1,328.8$ & -275.0 & 905.5 & $3,060.2$ \\
\hline Direct investment & 534.5 & 428.2 & -151.6 & 823.8 & 100.8 \\
\hline Portfolio investment & -3.1 & -72.6 & 28.5 & -26.9 & 36.7 \\
\hline Other investment & 335.9 & $-1,684.4$ & -152.0 & 108.6 & $2,922.6$ \\
\hline Errors and omissions & $-1,222.5$ & 911.7 & 943.2 & $1,101.0$ & -31.7 \\
\hline Overall balance & 584.5 & -87.1 & -6.8 & 843.0 & $2,525.8$ \\
\hline \multicolumn{6}{|l|}{ Memorandum items: } \\
\hline Current account/GDP (percent) & 6.8 & 2.2 & -4.1 & -7.4 & -1.4 \\
\hline Goods and services balance/GDP (percent) & 2.0 & -2.6 & -15.0 & -12.8 & -10.3 \\
\hline Gross official reserves (end of period) & $2,003.2$ & $1,688.9$ & $1,555.2$ & $2,486.4$ & $5,267.7$ \\
\hline In months of imports of goods and services & 2.1 & 1.5 & 1.3 & 1.9 & 3.6 \\
\hline Lilangeni per U.S. dollar (end of period) & 6.64 & 5.63 & 6.33 & 6.97 & 6.81 \\
\hline Lilangeni per U.S. dollar (period average) & 7.56 & 6.45 & 6.36 & 6.77 & 7.05 \\
\hline Exports fob, volume growth & 0.6 & 34.4 & -15.5 & -2.6 & -3.7 \\
\hline Imports fob, volume growth & -15.4 & -1.9 & -2.0 & -2.4 & 4.0 \\
\hline
\end{tabular}

Sources: Central Bank of Swaziland; and IMF staff projections.

${ }^{1}$ Without corrective policy measures.

${ }^{2}$ SACU: Southern African Customs Union. SACU transfers in the current account does not reflect the true level of SACU revenue because of the particular treatment of those transfers in the accounts where the authorities make an estimate based on the level of imports and adjust in 'other investment' to reflect the total SACU revenues. 
Table 29. Swaziland: Merchandise Exports, 2003-07

(In millions of U.S. dollars)

\begin{tabular}{|c|c|c|c|c|c|}
\hline & 2003 & 2004 & 2005 & 2006 & $\begin{array}{l}2007 \\
\text { Est. }\end{array}$ \\
\hline Sugar & 202 & 221 & 244 & 229 & 250 \\
\hline Wood pulp & 69 & 178 & 81 & 94 & 99 \\
\hline Asbestos & 0 & 0 & 0 & 0 & 0 \\
\hline Meat and meat products & 3 & 0 & 4 & 4 & 5 \\
\hline Canned fruit & 15 & 11 & 29 & 36 & 29 \\
\hline Citrus & 6 & 28 & 3 & 3 & 3 \\
\hline Coal & 6 & 25 & 7 & 8 & 13 \\
\hline Diamond & 0 & 0 & 0 & 0 & 0 \\
\hline Zippers & 10 & 20 & 25 & 28 & 31 \\
\hline Edible concentrates & 276 & 762 & 639 & 677 & 745 \\
\hline Wood and wood products & 17 & 0 & 14 & 18 & 21 \\
\hline Cottonseed and lint & 0 & 220 & 0 & 0 & 0 \\
\hline Chemicals & 0 & 0 & 0 & 0 & 0 \\
\hline Fruit squash & 6 & 20 & 11 & 18 & 15 \\
\hline Brake linings & 0 & 1 & 0 & 0 & 0 \\
\hline Cotton yarn & 14 & 0 & 19 & 26 & 21 \\
\hline Face bricks & 0 & 0 & 1 & 1 & 1 \\
\hline Footwear & 0 & 1 & 0 & 0 & 0 \\
\hline Other textiles & 149 & 0 & 249 & 261 & 251 \\
\hline Paper products & 8 & 26 & 6 & 9 & 11 \\
\hline Plastic products & 0 & 37 & 2 & 3 & 5 \\
\hline Refrigerators & 1 & 5 & 18 & 26 & 30 \\
\hline Ethanol & 9 & 0 & 6 & 8 & 8 \\
\hline Eucalyptus & 3 & 0 & 2 & 2 & 2 \\
\hline Television sets & 0 & 10 & 0 & 0 & 0 \\
\hline Windscreens & 0 & 1 & 0 & 0 & 0 \\
\hline Other food products & 37 & 0 & 51 & 63 & 70 \\
\hline Other/errors and omissions & 339 & 143 & 170 & 25 & 71 \\
\hline Total domestic exports & 1,170 & 1,709 & 1,580 & 1,539 & 1,678 \\
\hline Reexports & 217 & 100 & 56 & 125 & 90 \\
\hline Total exports, f.o.b. & 1,387 & 1,809 & 1,637 & 1,664 & 1,767 \\
\hline
\end{tabular}

Sources: Central Statistical Office; and Central Bank of Swaziland. 
Table 30. Swaziland: Sugar Exports by Volume, Value, and Unit Price, 2003-07

\begin{tabular}{|c|c|c|c|c|c|}
\hline & 2003 & 2004 & 2005 & 2006 & 2007 \\
\hline & \multicolumn{5}{|c|}{ (In thousands of metric tons) } \\
\hline \multicolumn{6}{|l|}{ Volume } \\
\hline Non-SACU & 279 & 296 & 320 & 320 & 319 \\
\hline European Union (EU) & 147 & 158 & 152 & 153 & 188 \\
\hline United States & 16 & 16 & 28 & 20 & 16 \\
\hline Other & 116 & 122 & 140 & 147 & 115 \\
\hline SACU $^{1}$ & 332 & 311 & 316 & 318 & 307 \\
\hline Total production ${ }^{2}$ & 628 & 598 & 653 & 623 & 631 \\
\hline & \multicolumn{5}{|c|}{ (In millions of emalangeni) } \\
\hline \multicolumn{6}{|l|}{ Value } \\
\hline Non-SACU & 787 & 745 & 835 & 981 & 1,126 \\
\hline EU & 596 & 576 & 559 & 593 & 869 \\
\hline United States & 44 & 34 & 64 & 46 & 37 \\
\hline Other & 147 & 135 & 211 & 341 & 220 \\
\hline SACU $^{1}$ & 874 & 801 & 842 & 919 & 962 \\
\hline & \multicolumn{5}{|c|}{ (In U.S. dollars per metric ton) } \\
\hline \multicolumn{6}{|l|}{ Average unit price } \\
\hline Non-SACU & 373 & 390 & 400 & 462 & 504 \\
\hline EU & 536 & 567 & 564 & 583 & 631 \\
\hline United States & 364 & 329 & 357 & 355 & 313 \\
\hline Other & 168 & 172 & 337 & 350 & 251 \\
\hline SACU $^{1}$ & 348 & 399 & 409 & 435 & 427 \\
\hline & \multicolumn{5}{|c|}{ (In emalangeni per metric ton) } \\
\hline \multicolumn{6}{|l|}{ Average unit price } \\
\hline Non-SACU & 2,821 & 2,517 & 2,606 & 3,066 & 3,524 \\
\hline EU & 4,054 & 3,657 & 3,672 & 3,870 & 4,616 \\
\hline United States & 2,750 & 2,125 & 2,323 & 2,353 & 2,294 \\
\hline Other & 1,267 & 1,107 & 1,505 & 2,324 & 1,912 \\
\hline SACU $^{1}$ & 2,633 & 2,576 & 2,662 & 2,888 & 3,130 \\
\hline
\end{tabular}

Source: Swaziland Sugar Association.

${ }^{1}$ The Southern African Customs Union (SACU) accounts for all sales to SACU countries and includes sales of sugar within Swaziland (normally about 10-15 percent of SACU sales).

${ }^{2}$ The difference between total production and total exports represents a change in stock. 
Table 31. Swaziland: Other Principal Exports by Volume, Value, and Unit Price, 2003-07

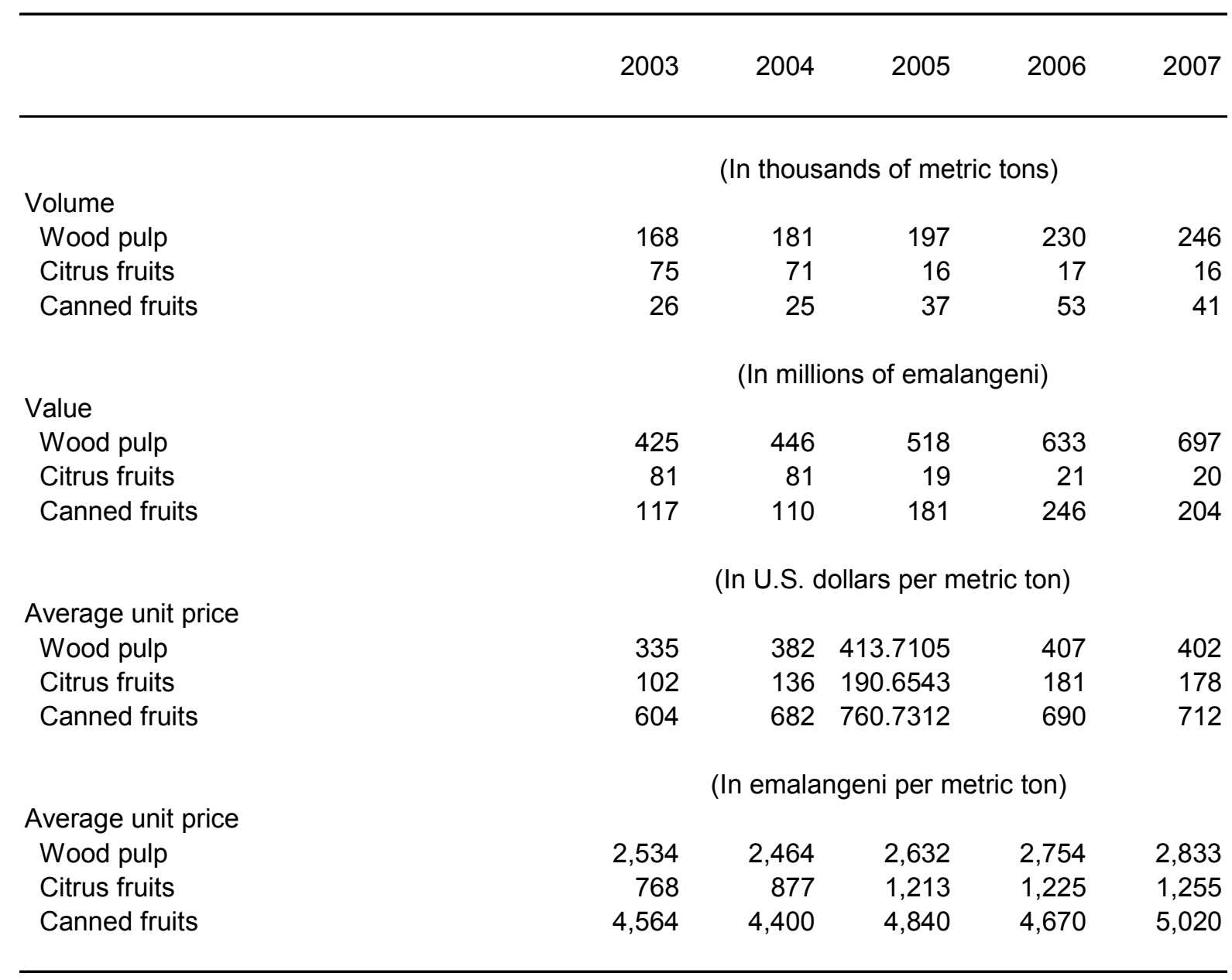

Source: Central Bank of Swaziland. 
Table 32. Swaziland: Merchandise Imports, 2003-07

(In millions of U.S. dollars, unless otherwise indicated)

\begin{tabular}{lrrrrr}
\hline & 2003 & 2004 & 2005 & 2006 & 2007 \\
\hline Food and live animals & & & & & \\
Beverages and tobacco & 176 & 280 & 244 & 295 & 280 \\
Inedible crude materials & 41 & 46 & 37 & 40 & 65 \\
Minerals, fuels, and lubricants & 43 & 58 & 60 & 60 & 68 \\
Animal and vegetable oils and fat & 133 & 235 & 288 & 252 & 212 \\
Chemicals and chemical products & 19 & 17 & 19 & 20 & 30 \\
Manufactures classified by material & 171 & 209 & 350 & 232 & 273 \\
Machinery and transport equipment & 316 & 302 & 273 & 326 & 396 \\
Miscellaneous manufactures & 128 & 183 & 364 & 451 & 502 \\
Commodities not classified by kind & 111 & 24 & 194 & 203 & 204 \\
& & & & & 177 \\
Total imports, c.i.f. & 1,387 & 1865 & 2,077 & 2,101 & 2,208 \\
Total imports, f.o.b. & 1,283 & 1,718 & 1,895 & 1,916 & 2,013 \\
& & & & & \\
\hline
\end{tabular}

Source: Central Bank of Swaziland. 
Table 33: Swaziland: Services and Income Account, 2003-07

(In millions of U.S. dollars)

\begin{tabular}{|c|c|c|c|c|c|}
\hline & 2003 & 2004 & 2005 & 2006 & 2007 \\
\hline Nonfactor services: credit & 193.1 & 250.0 & 282.4 & 283.5 & 454.1 \\
\hline Swaziland Railways & 15.5 & 6.6 & 6.3 & 7.2 & 8.9 \\
\hline Other shipment and transportation & 26.6 & 13.5 & 12.8 & 15.9 & 21.5 \\
\hline Travel & 124.7 & 64.0 & 78.3 & 85.4 & 102.6 \\
\hline Other official & 8.6 & 6.6 & 7.5 & 8.6 & 9.8 \\
\hline Other Private & 17.8 & 159.3 & 177.5 & 166.4 & 311.3 \\
\hline Nonfactor services: debit & -259.9 & -402.6 & -402.8 & -373.6 & -506.2 \\
\hline Shipment and tansp. & -97.3 & -66.9 & -75.6 & -86.3 & -102.5 \\
\hline Travel & -7.3 & -16.2 & -17.3 & -18.1 & -20.3 \\
\hline Other official & -15.2 & -9.5 & -8.2 & -7.6 & -10.1 \\
\hline Other Private & -140.1 & -320.4 & -301.7 & -261.6 & -373.3 \\
\hline Factor income: credit & 143.5 & 132.5 & 271.3 & 241.8 & 280.5 \\
\hline Investment income & 59.5 & 44.2 & 78.6 & 98.4 & 112.6 \\
\hline Official & 57.3 & 41.1 & 75.8 & 95.3 & 109.1 \\
\hline Private (incl. Property income) & 2.2 & 3.1 & 2.8 & 3.1 & 3.5 \\
\hline Labour income & 84.0 & 88.3 & 192.7 & 143.4 & 167.9 \\
\hline Factor income: debit & -102.8 & -125.1 & -93.0 & -227.8 & -216.8 \\
\hline Investment income & -58.4 & -61.8 & -56.1 & -148.8 & -128.2 \\
\hline Official \& Govnt. guaranteed & -18.1 & -21.2 & -7.2 & -94.5 & -67.0 \\
\hline Private & -40.3 & -40.6 & -48.9 & -54.3 & -61.2 \\
\hline Property income & -41.9 & -59.9 & -28.4 & -70.1 & -78.6 \\
\hline Labour income & -4.4 & -7.0 & -8.5 & -8.9 & -10 \\
\hline Services and income: credit & 336.7 & 382.5 & 553.7 & 525.3 & 734.6 \\
\hline Services and income: debit & -362.6 & -527.7 & -495.8 & -601.4 & -723.0 \\
\hline Services (net) & -66.7 & -152.6 & -120.4 & -90.1 & -52.1 \\
\hline Factor income (net) & 40.8 & 7.4 & 178.3 & 14.0 & 63.7 \\
\hline Total (net) & -25.9 & -145.2 & 57.9 & -76.1 & 11.6 \\
\hline
\end{tabular}

Source: Central Bank of Swaziland 
Table 34. Swaziland: Financial Account, 2003-07

(In millions of U.S. dollars)

\begin{tabular}{|c|c|c|c|c|c|}
\hline & 2003 & 2004 & 2005 & 2006 & 2007 \\
\hline Direct investment (net) & 70.7 & 66.4 & -23.8 & 121.7 & 14.3 \\
\hline Direct investment in Swaziland & 60.9 & 64.9 & -24.4 & 116.2 & 12.8 \\
\hline Equity capital & -3.8 & -4.8 & -53.4 & -6.0 & -59.1 \\
\hline Reinvestment of earnings & 11.2 & 34.5 & 16.4 & 68.4 & 48.2 \\
\hline Other long-term capital & 15.9 & 19.4 & 8.1 & 28.5 & 12.3 \\
\hline Other short-term capital & 37.6 & 15.8 & 4.5 & 25.3 & 11.4 \\
\hline Direct investment abroad & 9.8 & 1.4 & 0.6 & 5.5 & 1.5 \\
\hline Equity capital & 0.4 & 0.0 & 0.0 & 0.0 & 0.0 \\
\hline Reinvestment of earnings & 0.0 & 0.0 & 0.0 & 0.0 & 0.0 \\
\hline Other long-term capital & 0.3 & 0.0 & 0.2 & 1.5 & 0.4 \\
\hline Other short-term capital & 9.8 & 1.4 & 0.4 & 4.0 & 1.1 \\
\hline Long-term capital (net) & -45.0 & -68.5 & -80.0 & -108.6 & -118.3 \\
\hline Public sector (net) & -2.2 & 6.9 & 6.9 & 4.0 & 7.1 \\
\hline Loan drawings (liability) & 15.2 & 28.3 & 29.2 & 30.3 & 34.2 \\
\hline Loan repayments (liability) & -17.4 & -21.4 & -22.3 & -26.3 & -27.1 \\
\hline Sasol Funds (assets) & 0.0 & 0.0 & 0.0 & 0.0 & 0.0 \\
\hline Private sector (net) & -42.8 & -75.4 & -86.9 & -112.6 & -125.4 \\
\hline Private sector (liability) & -1.1 & 0.3 & 0.2 & 0.5 & 0.6 \\
\hline Corporate equity securities & -0.1 & -0.3 & -0.2 & -0.1 & 0.3 \\
\hline Loans (drawings and repayments) & -1.0 & 0.6 & 0.8 & 1.0 & 1.2 \\
\hline Private sector (assets) & -41.8 & -75.7 & -87.1 & -113.1 & -126.0 \\
\hline Corporate equity securities & 0.0 & 0.2 & 0.1 & 0.0 & 0.0 \\
\hline Debt securities (money markets) & -0.3 & -10.9 & -12.2 & -14.1 & 0.2 \\
\hline Loans (drawings and repayments) & -5.3 & 3.6 & 3.5 & 3.1 & 4.5 \\
\hline Other assets including pension funds & -36.1 & -68.6 & -78.5 & -102.1 & -130.6 \\
\hline Short-term capital (net) & 86.9 & -229.5 & 58.6 & 125.7 & 472.9 \\
\hline Public sector (net) & 97.1 & -203.0 & 86.9 & 141.0 & 493 \\
\hline Received under Southern African Customs Union (SACU) (lia & 280.4 & 272.9 & 474.5 & 704.4 & 719.2 \\
\hline Monetary authority currency/deposits (liability) & -2.7 & -50.3 & -62.0 & -50.6 & -25.6 \\
\hline Other liabilities & 0.0 & 0.0 & & & \\
\hline Receivable under SACU & -180.6 & -425.6 & -325.6 & -512.8 & -200.6 \\
\hline Private sector (net) & -10.2 & -26.5 & -28.3 & -15.3 & -20.1 \\
\hline Banks (net) & 32.5 & -3.2 & -6.8 & 11.1 & 9.2 \\
\hline Currency and deposits (assets) & 35.7 & -1.6 & -5.6 & 12.5 & 11.2 \\
\hline Other liabilities (liability) & -3.3 & -1.7 & -1.2 & -1.4 & -2.0 \\
\hline Other (net) & -42.7 & -23.3 & -21.5 & -26.4 & -29.3 \\
\hline Trade credit (liability) & 2.0 & -1.3 & 1.1 & 0.2 & -1.2 \\
\hline Other liabilities (liability) & -12.8 & -0.9 & -1.1 & -1.5 & -1.0 \\
\hline Trade credit (assets) & -50.2 & -2.2 & -1.2 & -1.5 & -2.0 \\
\hline Currency holdings & 18.3 & -18.9 & -20.3 & -23.6 & -25.1 \\
\hline Other (unrecorded) & 2.1 & 25 & 2.0 & 0.0 & 65.1 \\
\hline Financial and capital account balance & 114.6 & -206.6 & -43.2 & 133.8 & 434.1 \\
\hline
\end{tabular}

Source: Central Bank of Swaziland. 
Table 35. Swaziland: Public Sector External Debt, 2003-07 (In millions of U.S. dollars)

\begin{tabular}{|c|c|c|c|c|c|}
\hline & 2003 & 2004 & 2005 & 2006 & 2007 \\
\hline TOTAL DEBT OUTSTANDING & 414.5 & 484.1 & 435.2 & 441.6 & 498.4 \\
\hline PRIVATE DEBT (Unguaranteed) & 61.0 & 69.9 & 62.0 & 65.5 & 64.6 \\
\hline PUBLIC DEBT & 353.6 & 414.2 & 373.2 & 376.1 & 433.8 \\
\hline $\begin{array}{c}\text { of which : Central Government } \\
\text { Parastatal/Guaranteed }\end{array}$ & $\begin{array}{r}300.4 \\
53.2\end{array}$ & $\begin{array}{r}356.3 \\
57.9\end{array}$ & $\begin{array}{r}323.6 \\
49.6\end{array}$ & $\begin{array}{r}341.0 \\
35.1\end{array}$ & $\begin{array}{r}405.7 \\
28.0\end{array}$ \\
\hline Multilateral Org. & 169.5 & 214.8 & 223.5 & 230.7 & 252.0 \\
\hline IBRD & 10.8 & 22.4 & 21.0 & 21.0 & 19.4 \\
\hline IDA & 4.0 & 3.8 & 3.6 & 3.4 & 3.2 \\
\hline Arab League & 0.0 & 0.0 & 0.0 & 0.0 & 0.0 \\
\hline UN & 0.0 & 0.0 & 0.0 & 0.0 & 0.0 \\
\hline$A D B$ & 59.3 & 84.3 & 108.8 & 115.9 & 126.7 \\
\hline ADF & 60.3 & 68.2 & 50.2 & 48.1 & 49.2 \\
\hline NTF & 0.6 & 0.5 & 0.5 & 0.3 & 0.3 \\
\hline EDF/EIB & 30.7 & 32.8 & 36.2 & 36.1 & 45.6 \\
\hline IMF & 0.0 & 0.0 & 0.0 & 0.0 & 0.0 \\
\hline IFAD & 3.7 & 2.6 & 3.3 & 5.9 & 7.6 \\
\hline EDESA & 0.0 & 0.0 & 0.0 & 0.0 & 0.0 \\
\hline Bilateral & 150.4 & 158.4 & 92.1 & 89.1 & 119.2 \\
\hline $\begin{array}{l}\text { U.K. } \\
\text { Germany }\end{array}$ & $\begin{array}{r}1.3 \\
29.8\end{array}$ & $\begin{array}{r}1.4 \\
30.2\end{array}$ & $\begin{array}{r}0.6 \\
19.8\end{array}$ & $\begin{array}{r}0.3 \\
20.1\end{array}$ & $\begin{array}{r}0.0 \\
19.7\end{array}$ \\
\hline Denmark & 6.7 & 6.9 & 5.0 & 5.2 & 5.4 \\
\hline U.S.A. & 6.5 & 6.1 & 5.8 & 5.5 & 5.2 \\
\hline Canada & 0.0 & 0.0 & 0.0 & 0.0 & 0.0 \\
\hline Japan & 41.8 & 43.9 & 19.1 & 20.3 & 39.4 \\
\hline Italy & 1.1 & 1.0 & 0.0 & 0.0 & 0.0 \\
\hline South Africa & 44.4 & 50.6 & 23.8 & 20.4 & 20.9 \\
\hline Badea & 6.6 & 6.6 & 6.1 & 5.6 & 12.4 \\
\hline Kuwait & 8.1 & 7.9 & 8.4 & 8.2 & 8.4 \\
\hline Rep. of China & 4.0 & 3.8 & 3.6 & 3.3 & 7.7 \\
\hline Private Creditors & 33.7 & 41.1 & 57.6 & 56.3 & 62.6 \\
\hline
\end{tabular}

Source: Ministry of Finance and CBS.

CInternational Monetary Fund. Not for Redistribution 
Table 36. Swaziland: Public Sector External Debt Service, 2002/03-2007/08 (In millions of U.S. dollars)

\begin{tabular}{lrrrrr}
\hline & 2003 & 2004 & 2005 & 2006 & 2007 \\
\hline TOTAL DEBT SERVICE & 42.6 & 46.8 & 37.6 & 41.2 & 42.1 \\
Principal & 19.3 & 22.7 & 16.2 & 20.4 & 23.3 \\
$\quad$ Interest & 23.2 & 24.0 & 21.2 & 20.7 & 18.8 \\
Commitment fees & 0.1 & 0.2 & 0.2 & 0.1 & 0.1 \\
DISBURSEMENTS & 17.4 & 32.3 & 44.3 & 50.5 & 41.8 \\
\hline
\end{tabular}

Source: Ministry of Finance and CBS. 
Table 37. Swaziland: Commercial Banks' Performance Ratios, Dec. 2003-08

\begin{tabular}{|c|c|c|c|c|c|c|c|}
\hline & $\begin{array}{c}2003 \\
\text { Dec. }\end{array}$ & $\begin{array}{c}2004 \\
\text { Dec. }\end{array}$ & $\begin{array}{r}2005 \\
\text { Dec } \\
\end{array}$ & $\begin{array}{r}2006 \\
\text { Dec } \\
\end{array}$ & $\begin{array}{l}2007 \\
\text { June }\end{array}$ & $\begin{array}{r}2007 \\
\text { Dec } \\
\end{array}$ & $\begin{array}{l}2008 \\
\text { June }\end{array}$ \\
\hline & \multicolumn{7}{|c|}{ (Percent) } \\
\hline \multicolumn{8}{|l|}{ Performance Ratios } \\
\hline Basle capital ratio (Tier 1) & 14 & 14 & 15 & 20 & 23 & 21 & 18 \\
\hline Basle capital ratio (Tier 2) & 20 & 16 & 17 & 26 & 23 & 24 & 20 \\
\hline \multicolumn{8}{|l|}{ Asset Quality } \\
\hline Loans to deposit ratio ${ }^{1}$ & 75 & 73 & 83 & 86 & 88 & 105 & 86 \\
\hline Earning assets to total assets & 90 & 87 & 92 & 65 & 67 & 69 & 73 \\
\hline Nonperforming loans to total loans ${ }^{1}$ & 2 & 3 & 2 & 4 & 4 & 6 & 8 \\
\hline Reserve for losses to total loans & 9 & 8 & 7 & 10 & 9 & 8 & 6 \\
\hline \multicolumn{8}{|l|}{ Liquidity Ratios } \\
\hline Liquid assets to total deposits & 19 & 18 & 17 & 20 & 20 & 19 & 16 \\
\hline Available reserves to total deposits & 18 & 19 & 20 & 10 & 12 & 12 & 5 \\
\hline Liquid assets to total assets & 14 & 14 & 13 & 15 & 14 & 13 & 13 \\
\hline \multicolumn{8}{|l|}{ Profitability Ratios } \\
\hline Net income to average total assets (return on assets) & 4 & 3 & 3 & 6 & 3 & 3 & 4 \\
\hline Net income to average total equity (return on equity) & 29 & 20 & 20 & 52 & 26 & 15 & 14 \\
\hline Total expenses to total income & 60 & 64 & 68 & 71 & 74 & 63 & 68 \\
\hline
\end{tabular}

Source: Central Bank of Swaziland.

${ }^{1}$ Excluding the Swaziland Development and Savings Bank, which is owned by the government and offers both development finance and commercial banking services since its recapitalization and relaunch by the government in 2001 . 
Table 38. Swaziland: Summary of the Tax System as of July 31, 2008

(All amounts in emalangeni)

\begin{tabular}{l} 
Tax \\
\hline A. Central government \\
1. Taxes on net income and \\
profits
\end{tabular}

1.1 Taxes on companies

1.11 Company income tax (normal tax). Income Tax Order, 1975, as amended.
Annual income tax is levied on taxable income derived from sources in Swaziland, or deemed to be in Swaziland, by all companies, foreign or domestic, public or private. Agricultural cooperatives, insurance societies, and public utility companies are also considered companies for taxation purposes. Taxable income is defined as gross income (excluding capital receipts, and foreign and exempt income) less allowable deductions (including loss offsets) incurred in the process of production in Swaziland. The assessment year ends June 30 and tax (less provisional tax payments detailed below) is payable annually. Company tax legislation is integrated with personal income tax legislation. Consequently, where exemptions, deductions, and allowances normally appropriate for persons are appropriate for a particular company, these may be claimed (see 1.21 below). For farming companies, net change in livestock and produce held is deemed income (except for companies that opted otherwise under previous tax laws) and will be valued at purchase price or current market prices, whichever is lower.
Exemptions include, inter alia, dividend receipts of companies, receipts and accruals (including those from investments) of life insurance companies, pension benefits or provident funds. Also excluded are the noninvestment profits of societies and associations that are derived solely through transactions with individual members. (a) Companies: 30 percent of taxable income.

(b) Companies granted development approval order: 10 percent of taxable income.

\section{CInternational Monetary Fund. Not for Redistribution}




\begin{tabular}{l}
\hline Tax \\
\hline 1.11 Company income tax \\
(normal tax). Income Tax \\
Order, 1975, as amended. \\
(continued)
\end{tabular}

(continued) Nature of Tax
Provisional tax: a system of
provisional taxation is in operation in respect of all companies, directors of whose income, other than remuneration under the PAYE (payas-you-earn) scheme, exceeds E 1,000 per annum. Provisional taxpayers pay provisional tax on account of their final liability for normal tax for the year. The advance payments are to be made as follows: (a) on or before the last day of the six months of the year of assessment, one-half of the tax payable on the estimated income for the year; and (b) on or before the last day of the year of assessment, the total taxes payable on the estimated income for the year less the amount of the previous provisional tax payment. The estimated income for the year will normally not be less than the taxable income in the preceding year of assessment. In the case of a company, the year of assessment will be the year in respect of which its financial accounts are drawn up. Farmers are required to make one payment of provisional tax on or before the end of the year of assessment on the estimated income for the year. As an introductory measure, a "phasing-in" period of five years is provided for payment of provisional tax. One-fifth of the provisional tax due for 1985/86 would be payable in that year and so on until full provisional tax payments are due in 1990/91. In terms of the provisions of the Income Tax (Amendment) Act of 1994, all companies that are provisional taxpayers are required, in addition to the two existing provisional tax payments mentioned above, to make a third payment for year of assessment. This final payment is due six months after the close of the year of assessment, by which time the company will be in a position to accurately estimate its taxable income.
Exemptions and Deductions Rates

A new business engaged in a manufacturing industry that is not already in existence in Swaziland or, with effect from July 1, 1987, any business that is predominantly engaged in exporting goods from Swaziland is exempt from normal tax for the first five years unless the cumulative taxable income less cumulative local wage bill exceeds 150 percent of the value of the assets, in which case the excess shall be taxed. The Minister of Finance makes the final decision on whether a business is new, engaged in a manufacturing industry, is not already in existence in Swaziland, or is predominantly engaged in exporting goods from Swaziland.

Where the Minister of Finance is satisfied that a new business is beneficial to the development of the economy, he may, with prior approval of cabinet, declare that business a development enterprise, and he may issue a "development approval order" in respect of that business's granting additional tax concessions to it.

Deductions allowed include expenditures and losses incurred in the production of income (excluding capital expenditures and dividend payments), interest charges, "reasonable" depreciation allowances for plants, and 4 percent for buildings used in production, along with actual expenditures on repairs and maintenance. Any grant made to the University of Swaziland for the purpose of the university's undertaking capital projects in the form of buildings, fittings, and furniture, as well as other items associated with capital assets needed for the development of the university is exempt. An amount spent by a company as direct "listing" fees on the Swaziland Stock Exchange, subject to the proviso that only onethird of the expense is claimable in the year of expense; the balance is spread equally in the next two years. 


\begin{tabular}{l}
\hline Tax \\
\hline 1.11 Company income \\
tax (normal tax). Income \\
Tax Order, 1975, as
\end{tabular}

amended. (continued)
Exemptions and Deductions

Rates

Nature of Tax Contributions to pension schemes are limited to 20 percent of employee remuneration and annuities (less employees' contribution) up to E 1,750 per employee. The total contribution by a taxpayer to retirement annuity funds is limited to the greatest of (a) 15 percent of taxable income accruing to the taxpayer in respect of trade carried on by him, provided such amount shall not exceed E 5,000 per annum; or (b) E 3,500 less contributions made by the taxpayer to a pension fund; or (c) E 1,750. All expenses relating to the training of Swazi employees are also deductible (in effect 200 percent) for taxpayers engaged in an industry gazetted by the Ministry of Finance with approval of the scheme by the Commissioner. Expenditures, direct and indirect, for research related to production are also deductible at the rate of annual cost or 4 percent of the total contract value, whichever is greater.

Initial allowances are available for machinery or plants, infrastructural machinery, or facilities, including transmission equipment, and lines and pipes qualifying for wear-and-tear allowances as well as for buildings housing such machinery or plants and used by the taxpayer for the first time in a manufacturing business at the rate of 50 percent granted in the first year of assessment during which the machinery or plant or building was first used.

Companies that are considered approved companies in the handicraft and cottage industry sector and companies considered to be engaged in the export of products from the handicraft and cottage industry sector ("export trading houses") are permitted to deduct from income (i.e., in addition to the normal amounts permitted under the General Deduction Formula) additional 


\begin{tabular}{l}
\hline Tax \\
\hline 1.11 Company income tax \\
(normal tax). Income Tax \\
Order, 1975, as amended. \\
(concluded)
\end{tabular}

1.12 Casino tax. Casino Tax Act, 1963, (Act No. 56, 1963, as amended).
Nature of Tax

Exemptions and Deductions amounts of 133 percent (for the cottage industry) and 150 percent ("approved export trading houses") in respect of "approved export promotion expenditure," as defined. The additional expenditure allowance is subject to the company's achieving an increase in volume of exports in the subsequent year.

Contributions, whether in cash or in kind, made during the year of assessment toward any national disaster scheme established by the government.

Farming: special (100 percent) deductions (not exceeding 30 percent of gross income) are allowable for a variety of on-farm expenditures (e.g., irrigation and fencing). Where these deductions are made, initial and depreciation allowances are not allowable.

With effect from July 1, 1985, it is composed of an annual license fee and of a levy based on a percentage of the gross gaming room takings of the licensee less any amount paid out as winnings to casino patrons and is payable on an annual basis. A licensee is liable to normal tax.
Rates

(a) The annual license fee is E 2,000.

(b) A levy payable on the gross gaming room takings of the licensee less any amount paid out as winnings to casino patrons, as follows:

- In respect of the first year of operation of the casino, no levy shall be paid.

- In respect of the second, third, fourth, fifth, and sixth years of operation of the casino, a levy of 2.0 percent shall be paid.

- In respect of the seventh year and subsequent years of operation, a levy of 4.5 percent shall be paid. 


\begin{tabular}{l}
\hline Tax \\
\hline 1.21 Individual income \\
tax (normal tax). Income \\
Tax Order, 1975, as \\
amended.
\end{tabular}

amended.
Nature of Tax
This is payable, subject to the
deductions and exemptions noted, on income received by or accruing to all persons from sources within Swaziland or deemed to be within Swaziland. Tax is payable on assessed "taxable income," which is equal to gross income (excluding capital receipts and exempt income) less losses and allowable deductions. Taxable income includes, inter alia, annuities, wages and salaries, rent investment income, and benefits in kind (e.g., free housing). After the calculation of taxable income and, hence, tax payable, certain "tax abatements" may be deducted where applicable. With effect from July 1, 1991, both men and women are subject to a uniform system of taxation. (See below under "rates.")
Employees are subject to a monthly withholding at source; other taxpayers are assessed annually. Nonresidents are liable for income tax on income earned in Swaziland (including benefits in kind received for services rendered); however, dividends and interest payments are subject to special taxes (see 1.31 and 1.32). Personal income tax legislation is integrated with company tax interest received by nonresidents from Swaziland government securities and bonds; and capital sums due from a provident fund or benefit fund (pension one third of the total value of the annuity to which any employee becomes entitled may be commuted for a single payment); capital sums in commutation of a retirement annuity; gratuities to a maximum of 25 percent of total remuneration in respect of services rendered prior to 1 July, 2001. Severance allowance or notice pay payable under the Employment Act to an employee on the termination of his services is exempt from normal tax. The first E 30,000 received by or accrued to an individual on retrenchment or retirement. legislation. Consequently, where exemptions, deductions, and allowances normally appropriate for companies are applicable to persons (e.g., owner-occupied farms), these may be claimed. For farmers, net change in produce and livestock held is deemed income (except for those farmers who opted otherwise under previous tax laws) and will be valued at the lesser of the purchase price or current market price (if purchased), and at standard book valuation otherwise.

A system of provisional tax is in operation in respect of self-employed persons and other individuals whose income, other than remuneration subject to PAYE, exceeds

\begin{tabular}{|c|c|c|}
\hline Exemptions and Deductions & \multicolumn{2}{|l|}{ Rates } \\
\hline Exemptions include, inter alia, every & \multicolumn{2}{|c|}{$*_{\text {see attached Income Tax }}$} \\
\hline person who is ordinarily resident in & \multicolumn{2}{|c|}{ Amendment Bill of 2004} \\
\hline $\begin{array}{l}\text { Swaziland whose taxable income in } \\
\text { one year of assessment does not }\end{array}$ & \multirow{2}{*}{\multicolumn{2}{|c|}{$\begin{array}{l}\text { proposing adjustments for fiscal } \\
\text { drag. }\end{array}$}} \\
\hline $\begin{array}{l}\text { exceed } E 14,000 \text { per annum. Other } \\
\text { exemptions include the following. }\end{array}$ & & \\
\hline $\begin{array}{l}\text { exemptions include the following: } \\
\text { salaries of U.K. and South African }\end{array}$ & $\begin{array}{l}\text { Taxable income } \\
\text { (in Emalangeni) }\end{array}$ & $\begin{array}{r}\text { Marginal } \\
\text { tax rate }\end{array}$ \\
\hline civil servants; consular personnel not & & (In percent) \\
\hline permanent residents of Swaziland; & $0-14,000$ & 0 \\
\hline ; the first & $14,001-20,000$ & 12 \\
\hline E 1,000 of interest income received & $20,001-30,000$ & 19 \\
\hline by or accrued to an individual from a & $30,001-36,000$ & 26 \\
\hline deposit in a financial institution; & 36,000 & 33 \\
\hline
\end{tabular}

Trust income

33 percent of taxable income

Rates of normal tax in the case of a retiring or redundant individual

$\begin{array}{lc}\begin{array}{c}\text { Taxable income } \\ \text { (in Emalangeni) }\end{array} & \begin{array}{c}\text { Marginal tax } \\ \text { rate } \\ \text { (In percent) }\end{array} \\ * 30000-60000 & 12 \\ 60,001-90,000 & 19 \\ 90,001-120,000 & 26 \\ 120,001 & 33 \\ \text { *Income Tax (Amendment) Order } \\ 2003\end{array}$




\begin{tabular}{l}
\hline Tax \\
\hline 1.21 Individual income \\
tax (normal tax). Income \\
Tax Order, 1975, as \\
amended. (concluded)
\end{tabular}

amended. (concluded)
1.22 Graded tax. Graded Tax Act of 1968, as amended.

1.31 Tax on nonresidents' interest receipts. Income Tax Order, 1975, as amended.
Nature of Tax
Exemptions and Deductions
E 1,000 per annum (see 1.11 above).
One of the important amendments
introduced in the Income Tax
(Amendment) Act No. 6 of 1994 was the introduction of the Final
Deduction System (FDS) for employees, which came into operation on July 1, 1993. FDS constitutes a final liability to tax and is related to a full year of assessment. All employees, no matter how much they earn, are subject to the FDS, provided they have not derived any other taxable income during the year of assessment. Such employees are not required to furnish an income tax return if the income consists solely of employment income that is subject to FDS. (see 1.32 below).
Deductions include, in addition to those for companies (1.11 above) where appropriate, employee contributions to pension funds (maximum E 1,750 where the pension fund is not established by law).
Death, accident, sickness, or unemployment insurance and contributions to provident and benefit funds (other than a medical aid fund) are also deductible at a rate of 10 percent to a maximum of E 180 . To receive this deduction on death, accident, and sickness insurance premiums on policies entered after July 1, 1974, the policy must be with the Swaziland Royal Insurance Corporation.

This tax is payable by all persons (apart from the exemptions noted) resident or domiciled in Swaziland, and is thus akin to a head tax. Tax is determined on the basis of gross income and is payable annually for all except for employees whose deductions are made monthly at source.

This tax is payable by persons or the estate of a deceased person not resident in Swaziland or a company not registered in Swaziland on accrued interest where the debtor (person or company) is domiciled in Swaziland. The recipient is legally liable for the payment of this tax within 14 days of the accrual of interest, but it is normally paid by the debtor and deducted from interest remitted.
Exemptions include all persons under the apparent age of 18 , women earning less than E 15 per month, visitors, students, and the chronically ill.

Exemptions: interest on loans specifically exempt by government (usually government and other public body loans); building society shares; interest from loans to agricultural cooperatives and public utilities established by parliament; interest received by church, charitable, or educational organizations; and interest amounting to $\mathrm{E} 20$ or less in a importers' bills or notes is exempt where these have been handled through the banking system. full tax year. Also, interest on
Rates

Tax due is determined on the basis of gross income as shown below:

Gross income Tax payable
E 0 - E 299
E 4.20
E 300 - E 449
E 6.00
E 450 - E 600
E 12.00
Over E 600
E 18.00

Tax is payable at 10 percent of the interest accrued.

\section{CInternational Monetary Fund. Not for Redistribution}




\begin{tabular}{l}
\hline Tax \\
\hline 1.32 Tax on nonresident \\
shareholders. Income Tax \\
Order, 1975, as amended.
\end{tabular}

1.33 Tax on branch profits.

1.34 Tax on nonresident contractors. Income Tax Order, 1975, as amended.

1.35 Tax on nonresident. for Swaziland source services contract. Income Tax Order, 1975, as amended.

1.36 Tax on nonresident entertainers and sportsmen. Income Tax Order, 1975, as amended.
This tax is payable by persons or the estate of a deceased person not resident in Swaziland or any company not registered in Swaziland on dividends received from a company domiciled in Swaziland. This tax is payable on both interim and final dividends and is due within 30 days. Legal liability for payment resides with the recipient, but is normally paid by the payer and deducted from remitted dividends.

Tax is payable on the deemed repatriated income of a branch of a nonresident company.
Nature of Tax

Exemptions and Deductions Exemptions include dividends paid by agricultural cooperatives and dividends received by church, charitable, or educational institutions, as well as dividends accruing to a nonresident shareholder, which the government has, in terms of a written undertaking, exempted from tax.

No exemptions

This tax is payable by every person who makes payment to a nonresident person under an agreement relating to construction operations. The tax is deducted from each payment made to the nonresident. The nonresident is not relieved from any obligations to furnish returns for income tax and any assessment raised on the nonresident for income tax will be credited with the nonresident contractors' tax that has been paid on his behalf.

Tax is payable by all nonresident persons on amounts derived by the nonresident from performance of services that gives rise to Swaziland source income. The tax is payable on gross amount at source by withholding. The tax is a final tax.

This tax is payable by all nonresident entertainers and sportsmen who perform in Swaziland. The tax is payable on remuneration or gross receipts of any theatrical, musical, or sports performance where these receipts are received directly by the performers concerned. Legal liability for payment resides with the recipients. However, the payer is legally required to withhold the tax due from any remuneration payable.
No exemptions.

No exemptions.

Tax is payable at the rate of 15 percent.

Tax is payable at the rate of 15 percent

\section{CInternational Monetary Fund. Not for Redistribution}




\begin{tabular}{l}
\hline Tax \\
1.37 Tax on royalties and \\
management charge paid \\
to nonresident persons. \\
Income Tax Order, 1975, \\
as amended. \\
1.38 Tax on interest paid \\
to residents. Income Tax \\
Order, 1975, as amended.
\end{tabular}

1.39 Withholding tax on dividends paid to resident persons

1.40 Tax clearance certificates.

2. Social security
contributions

3. Taxes on property

3.1 Real estate taxes
Exemptions and Deductions

This tax is payable by nonresident persons on gross amount of any royalty and management charge derived from a source in Swaziland. The tax is withheld at source and it is a final tax.

This tax is payable by residents on the gross amount of interest derived from every financial institution. The tax is withheld at source. It is a final tax.

Tax is payable by a person (other than a company) resident or carrying on business in Swaziland.

A system of tax clearance is in operation. In terms of a gazette regulation published recently, tax clearance is presently needed for the issue, renewal, or transfer of any license, other than renewal of motor vehicle licenses, or similar document relating to any trade, business, profession, or vocation; the transfer of immovable property or any endorsement to any title deed having the effect of transferring property; the registration or deregistration of a company; first registration of motor vehicles in Swaziland; and the tendering for the provision of goods or services to the government or a parastatal body, in excess of E 5,000.

None.

See 3.42 .
There are no exemptions.

Rates

Tax is payable at the rate of 15 percent.

There are no exemptions.

Tax is payable at the rate of 10 percent.

Tax is payable at the rate of 10 percent.
The rate of tax varies with the size, or dutiable value, of the estate. The formula for determining the rate is as follows: for every E 200 (or part thereof) in dutiable value, the tax rate rises by 0.015 percent. This is subject to a maximum tax rate of $33^{1 / 3}$ percent (reached at a dutiable estate value of $\mathrm{E} 445,667$ ). 


\begin{tabular}{l}
\hline Tax \\
\hline 3.2 Tax on unutilized land \\
Land Tax Order, 1974, \\
King's Order-In-Council \\
No. 35, 1974. \\
\\
3.3 Death and succession \\
duties \\
All death and succession \\
duties under the Death \\
Duties Act, 1942, were \\
abolished by the Death \\
Duties (Repeal) Act, \\
1985.
\end{tabular}

\subsection{Property transfer tax}

3.41 Transfer duty, Chapter 107 of the Laws, Revised Edition, 1959.

3.42 Mineral rights tax. Mineral Rights Tax, Order No. 34, 1973.

\section{Taxes on goods and} services

Nature of Tax

Exemptions and Deductions

Rates

This tax, which came into force on

June 1, 1975, is levied by a Land

Taxation Board on land deemed underdeveloped after a hearing initiated by the Minister of Agriculture (for agricultural land) or the Minister of Local Administration (for urban land). Tax may be levied on all or part of a property owner's land.

Duty is levied on the sale or longterm lease of fixed property situated in Swaziland. The person liable for payment of the tax is the party acquiring title to the property, or entering into a lease of 25 years duration (or longer), or entering into the lease of a claim for mineral rights for any period. The base for this tax is the value of the property being acquired or leased.

Holders of mining rights are subject to taxes with respect to properties able to produce precious and nonprecious metals to which they hold rights. There are three distinct taxes that are grouped together: (a) a tax on the transfer of mining rights; (b) a ground tax on mineral rights; and (c) a capital gains tax.
Exemptions include, inter alia, transfers of property by gift for public, municipal, religious, or charitable uses. Also, government purchases and purchases by public hospitals (for the sole use of the hospital) are exempt. Additionally, settlement of jointly owned property between married persons upon divorce, or on the death of one party, is exempt.

None.
The rate of this duty is 2 percent on the first E 40,000 of transferred property value and 4 percent of any amount exceeding E 40,000, but only E 60,000 and 6 percent on any amount exceeding E 60,000.

(a) Transfer of mining rights is taxed at the rate of $271 / 2$ percent on the first E 20,000 of transferred value and 37 1/2 percent above E 20,000.

(b) The tax on unexploited rights is E 10 per ha. in each of the first five years, rising to $\mathrm{E} 50$ per ha. thereafter, if there has been no exploitation.

(c) The tax on gains from shares in mineral rights is $371 / 2$ percent of that gain. 


\begin{tabular}{ll}
\hline Tax & Nature of Tax \\
\hline 4.1 Sales tax & A tax levied at the import and \\
Sales Tax Act (Act. & manufacturing levels. To be collected \\
No. 12 of 1983). & on certain services and all goods other \\
& than those specifically exempted. \\
& Where payable on goods imported \\
& from outside the customs union area, \\
& valuation is 110 percent of customs \\
& value plus customs duties payable. \\
& Proceeds received are directly paid to \\
& the Swazi government, and are not \\
& paid into the SACU pool.
\end{tabular}

4.2 Selective excises Customs and Excise Act (Act No. 21 of 1971).

Specific duties are payable by the importer or manufacturer of beer, tobacco, and cigarettes. Rates are
Exemptions and Deductions

Many exemptions: necessities and

intermediate goods for manufacturing

are all mostly exempt along with certain medical supplies, temporary imports, certain personal imports, electricity, etc. those set by South Africa, with proceeds pooled under the Customs Union Agreement.

Exemptions are extended to exported goods.
Rates

14 percent on imported and locally manufactured or produced goods.

25 percent on all kinds of alcoholic beverages (imported or locally brewed), except traditional beer.

14 percent on traditional beer.

14 percent on accommodation let $\&$ food supplied by hotels or restaurants.

20 percent on locally manufactured tobacco products. 25 percent on imported tobacco products.

Rates of excise duty are mostly specific. Examples of these rates include the following:

(1) malt beer $340 \mathrm{ml} \mathrm{E} \mathrm{43.57;}$

(2) Sorghum beer 1 liter E 7.82;

(3) Spirits (average) $750 \mathrm{ml} \mathrm{E}$ 1,184.00;

(4) Sparkling wine 1 liter E 227.60;

(5) Fortified wine 1 liter E 182.50;

(6) Unfortified wine 1 liter E 80.70;

(7) Cigarettes 20 E 350.80;

(8) Pipe tobacco 25 grams E 131.30 . 


\begin{tabular}{ll}
\hline Tax & Nature of Tax \\
\hline 4.3 Business and & Annual license fees are charged for \\
professional licenses & betting shops, companies with a place \\
Trading Licence Act, & of business in Swaziland, persons or \\
1975. & companies trading in Swaziland, and \\
& $\begin{array}{l}\text { establishments licensed to sell or } \\
\text { serve liquor. }\end{array}$
\end{tabular}

4.4 Motor vehicle taxes

Motor vehicle license fees. Road Traffic Act, 1965.
Exemptions and Deductions

None.

License fees are levied on an annual basis. Rates vary with both the type and weight of the vehicle.
None.

*Annual fees for motor vehicles are:

Motorcycles

E60.00;

Motorcycles (with sidecar)

E 60.00; Tractors

E 60.00 ;

Tractors (with trailer) E60.00;

Earthmover E 150.00.

Other vehicles (by weight):

$\begin{array}{lc}\text { Kilograms } & \text { Emalangeni } \\ 1-1,000 & 70-100 \\ 1,001-2,000 & 110-145 \\ 2,001-3,000 & 170-220 \\ 3,001-4,000 & 235-290 \\ 4,001-5,000 & 300-345 \\ 5,001-6,000 & 360-405 \\ 6,001-7,000 & 420-465 \\ 7,001-8,000 & 480-525 \\ 8,001-9,000 & 555-585 \\ \text { *The Road Traffic (Amendment of } \\ \text { Schedule) Notice, 2004 }\end{array}$




\begin{tabular}{lll}
\hline Tax & Nature of Tax & Exemptions and Deductions \\
\hline $4.5 \quad$ Fuel oil levy & Levy on petroleum products. & $\begin{array}{l}\text { Exemptions for projects initiated a } \\
\text { regional level like Southern Africa } \\
\text { Development Community (SADC) }\end{array}$ \\
Fuel tax & $\begin{array}{l}\text { Exemption on fuel used by rail and } \\
\text { diplomats and His Majesty and the } \\
\text { Indlovukazi (Queen Mother) }\end{array}$
\end{tabular}

Fuel oil levy

Motor Vehicle Accident (MVA) Fund

Sales tax

\section{Taxes on international} trade and transactions

\subsection{Duties on imports} Customs Union Agreement, 1969 Legal Notice (No. 71 of 1969) and Customs, Fiscal, Excise, and Sales Duties Act, 1971 (Act No. 21 of 1971).

\subsection{Taxes on exports}

5.21 Sugar levy. Sugar Export Levy Act No. 4 of 1997.
A common taxation system is levied on imports in conjunction with Botswana, Lesotho, Namibia, and South Africa. Import duties are levied at the point of entry into the common customs area and thereafter the imports are free to move within the entire area. The importer is legally liable for the payment of these duties, the proceeds of which are pooled and divided among the countries according to a formula. Duty rates are set by South Africa on the basis of the six-digit Harmonized Commodity Description and Coding System. The rate structure includes general and most-favored-nation clauses. Most duties are ad valorem with specific duties on some items.

The sugar export levy is a tax on all sugar exported from Swaziland to the EU. The levy is collected from the millers and growers by the Swaziland Sugar Association (SSA), which then remits it on a quarterly basis to the government.
As above.

As above.

As above.

Rebates, remissions, and refunds of import duties are allowed in some cases (mostly for raw materials and semimanufactures). As with duty rates, such rebates must conform to South African rebates.

None.

No longer enforced, but not yet repealed.
Rates

40 cents per liter.

10 cents per liter

18 cents per liter

Customs \& excise 4 cents per liter;

Sales tax 14 percent of import parity (changes are usually undertaken anytime deemed necessary).

There are 45 ad valorem rates, ranging from 0 to over 70 percent.
5.22 Cattle export slaughter tax. Details not available.

6. Other taxes
The levy is on the net ex-mill protocol sales to the European Union to be applied two years in arrears. Net ex-mill export protocol sales proceeds are the Swazi currency equivalent of the gross amount received by the association in respect of all sales of sugar exported, less expenses as prescribed in the act and is payable on a quarterly basis. 


\begin{tabular}{l}
\hline Tax \\
\hline 6.1 Stamp taxes \\
Chapter 100 of the Laws, \\
1959. The Stamp Duties \\
Act, 1970 (Act No. 37) \\
and 1974 (Act No. 13), as \\
amended by the Finance \\
Act of 1985. \\
6.2 Miscellaneous \\
licenses \\
The Registration of Dogs \\
Act, 1953, as amended by \\
the Finance Act, 1985. \\
B. Local taxes \\
Property tax. Legal \\
reference not available.
\end{tabular}

\begin{abstract}
Nature of Tax
These taxes, which are mostly ad

valorem with some specific taxes, are

payable on a wide range of legal

documents (affidavits, bills of

exchange, checks, bonds, contract notes, receipts, property transfers, etc.).
\end{abstract}

These are charged for dog licenses.

None, but the law is not enforced; however, it has not been repealed.

Taxation in the form of rates is collected in the two principal towns (Mbabane and Manzini). Land and improvements are taxed at different rates with quinquennial valuation assessments. If changes in tax rates are desired by the town councils, approval is required by the central government before such changes can be enforced.
Exemptions and Deductions

Government and specified public enterprises.

Exemptions include governmentowned property.
Rates

Stamp duties vary considerably. For example, checks carry a 6 percent stamp duty, receipts for payments of $\mathrm{E} 2$ or more carry an E 0.10 duty, customs bills of entry an E 0.40 duty, and affidavits, agreements, and contracts an E 1 stamp duty.

Dog license tax is E 1 per annum in rural areas and E 3 per annum in urban areas.

Rates are assessed at 4 percent of the land value and 0.5 percent of the value of improvements in both towns. 


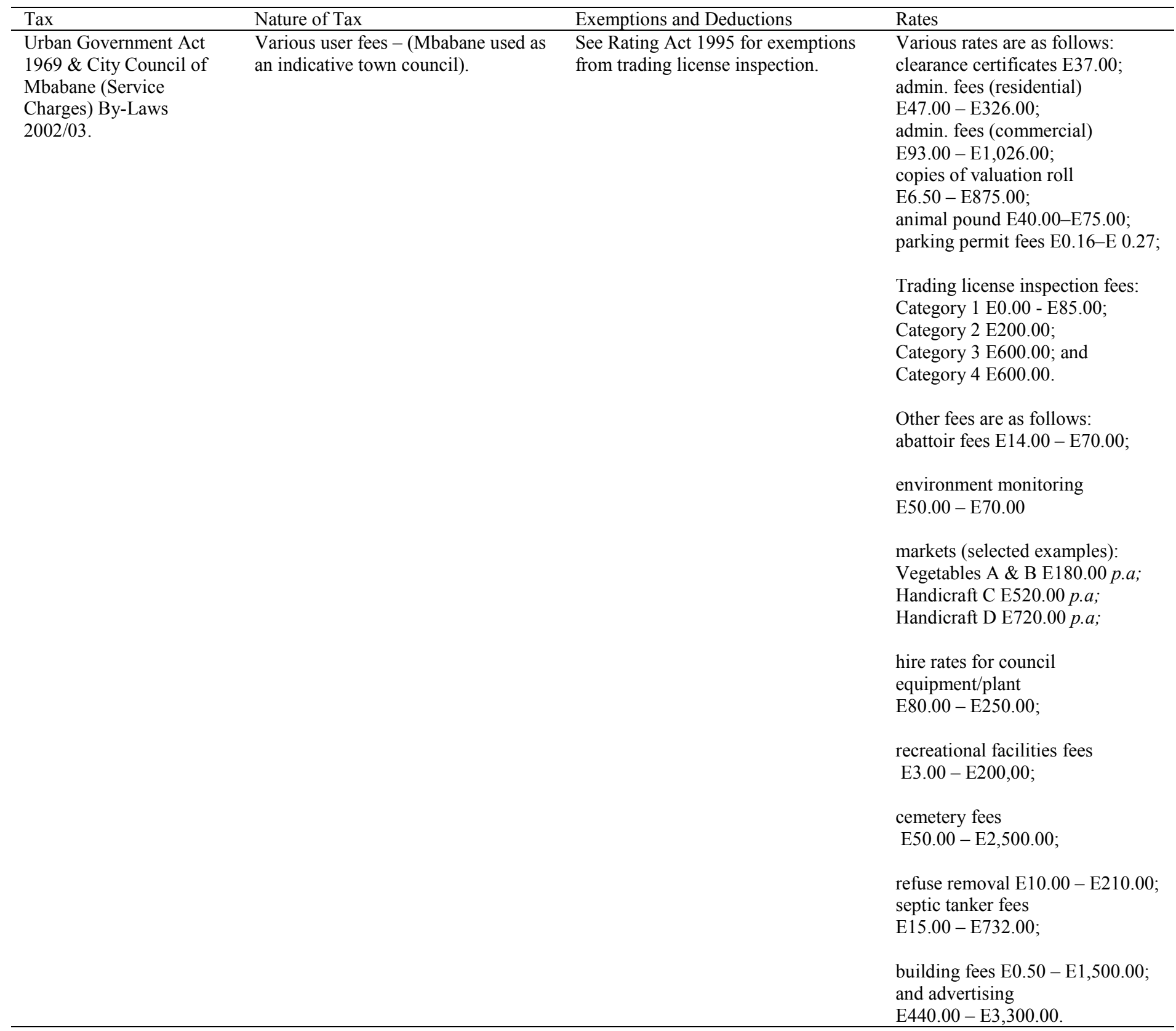

Sources: United Kingdom Board of Internal Revenue, Income Taxes Outside the United Kingdom, Vol. 7 (1972); International Bureau of Fiscal Documentation, Tax System; International Monetary Fund, Surveys of African Economies, Vol. 5; and Swaziland, Government Information Services, A Handbook to the Kingdom of Swaziland, various years, updated by the Swazi authorities. 